\title{
Old captains at the helm: Chairman age and firm performance
}

\author{
Urs Waelchlia, ${ }^{\mathrm{a},}$, Jonas Zeller ${ }^{\mathrm{b}}$ \\ ${ }^{a}$ Institut für Finanzmanagement, Universität Bern, Engehaldenstrasse 4, 3012 Bern, Switzerland \\ ${ }^{\mathrm{b}}$ Institut für Finanzmanagement, Universität Bern, Engehaldenstrasse 4, 3012 Bern, Switzerland
}

This version: December 12, 2012

\begin{abstract}
This paper examines whether the chairmen of the board (COBs) impose their life cycles on the firms over which they preside. Using a large sample of unlisted firms, we find a robust negative relation between COB age and firm performance. COBs age much like 'ordinary' people. Their cognitive abilities deteriorate, and they experience significant shifts in motivation. Deteriorating cognitive abilities are the main driver of the performance effect that we observe. The results imply that succession planning problems in unlisted firms are real. Mandatory retirement age clauses cannot solve these problems.
\end{abstract}

JEL classification: G30; L20

Keywords: Age; Chairman of the board; Cognitive abilities; Firm performance; Corporate governance; Unlisted firms; Survey.

* Corresponding author. Tel.: +41 31631 4091; fax: +41 316318424.

E-mail addresses: urs.waelchli@ifm.unibe.ch (U. Waelchli), jonas.zeller@ifm.unibe.ch (J. Zeller). 


\section{Introduction}

Extensive literature in economics, psychology, and sociology documents a negative relation between an individual's age and job performance. On average, older individuals perform more poorly in a broad spectrum of cognitive tasks (see, for example, Verhaeghen and Salthouse, 1997), experience a shift in motivation (see, for example, Ebner et al., 2006), and seem to prefer a quieter life (Bertrand and Mullainathan, 2003; Li et al., 2011). These effects often emerge before the age of 50, evolving progressively as individuals grow older. This paper asks whether aging agents affect firm performance and why that could be the case. Because firms, in principle, can adjust their control structures, one would expect performance to be unrelated to the age of the company's captain.

The data tell a different story. Using a unique dataset from a recent survey of more than 1,500 chairmen of the board (COBs) of unlisted corporations in Switzerland, we document a strong and robust negative relation between $\mathrm{COB}$ age and various measures of firm performance. In a linear estimation, the numbers indicate that an increase in $\mathrm{COB}$ age of one standard deviation (9.6 years) is associated with a drop in return on assets of 0.8 percentage points. This corresponds to a performance decline of approximately 10 percent for the average firm. Non-parametric regressions reveal that the deleterious effect of $\mathrm{COB}$ aging starts at approximately age 50 and bottoms out at approximately age 65-Switzerland's official retirement age. Therefore, it appears that underperforming COBs use the official retirement age as a face-saving exit option.

To the best of our knowledge, we are the first to document a COB age effect in unlisted firms. This finding should contribute to the literature that asks whether individual managers matter for firm performance (see, for example, Bertrand and Schoar, 2003). It also corroborates the view that COBs are among the most prominent players in a corporation (Parker, 1990; Mace, 1986). It is their responsibility to establish and secure effective corporate governance (Florou, 
2005) and to make sure that the board fulfills its central duties. According to the Swiss Code of Obligation (\$716a), the board's non-transferable and inalienable duties include, among other things, the overall management of the company, the appointment and dismissal of management, and the monitoring of management. A growing body of literature on CEO-COB duality argues that the COB has important monitoring functions (Yermack, 1996; Dahya et al., 2002). Such internal monitoring would seem particularly relevant for unlisted firms because they often lack external mechanisms that could act as substitutes (Booth et al., 2002; Kim and Lu, 2011) and have no liquid stock market that allows (minority) shareholders to walk away.

The puzzling question is why COBs overstay. Several tests indicate that the answer to this question is related to the relatively weak corporate governance standards of unlisted firms (see also Loderer and Waelchli, 2010). When we replicate our analysis for a comparison sample of listed Swiss firms, we find profitability to be unrelated to the individual age of the COB (and other top managers). This finding is consistent with previous studies for listed firms in the U.S. (see, for example, Bhagat et al., 2010). Therefore, our results seem to apply to unlisted firms and not to firms at large. Corporate governance also plays an important role within the sample of unlisted firms. For example, we find the $\mathrm{COB}$ age effect to be stronger for firms with a more dispersed ownership structure, possibly because collective action problems among shareholders make it more difficult to monitor the monitor (Brickley et al., 1997).

Previous literature shows that the more extensive experience of older individuals can at least partially counteract the deleterious effects of aging (see, among others, Korniotis and Kumar, 2011). This finding is also true for our sample. However, the combined effect of age and experience is still negative and significant.

In addition to experience, a factor that we control for throughout the investigation, Salthouse (2012) argues that an individual's cognitive abilities ('can do') and motivation ('will 
do') are the two main age-related determinants of job performance. Our unique dataset allows us to construct various measures of these determinants of job performance and to inquire into their relevance. Consistent with the extant literature, we find that cognitive abilities decline with age: older COBs perform significantly worse on a simple speed measure - the time it takes to fill in the questionnaire (see, among others, Park and Reuter-Lorenz, 2009) — and they are more likely to concede that job complexity has increased. Also the 'will do' function seems to deteriorate with age. We find that 1) older COBs are less likely to focus on shareholder value maximization; 2) older COBs prefer 'bureaucratic' activities over strategic tasks; and 3) older COBs are less appreciative of performance-sensitive compensation. This evidence is broadly consistent with the typical patterns of older individuals as documented in the extant literature.

We ask whether the age-related changes in abilities and motivation that we observe explain why performance slows as $\mathrm{COBs}$ grow older. We show that the $\mathrm{COB}$ age effect is mainly driven by deteriorating cognitive abilities. In particular, profitability is significantly lower in firms with 'slow' COBs (that is, COBs who perform poorly on our speed measure) than in firms with 'quick' COBs. We also find motivational factors to be important, albeit to a lesser extent. Accordingly, COBs who state a commitment to shareholder value maximization are associated with slightly better firm profitability. Together, these two factors are able to fully explain the COB age effect.

To the best of our knowledge, our study is the first to identify the channels through which COB age and firm performance are related. This finding should add to the literature in at least two ways. First, knowing that 'age' essentially reflects cognitive abilities at the corporate helm contributes to a better understanding of the existing findings in the literature, for example with respect to age-related differences in investment (Korniotis and Kumar, 2011) and acquisition (Yim, 2010) behavior. Second, it is important to understand the sources of the age effect before 
trying to find a possible remedy. Stricter monitoring and more performance-sensitive compensation do not cure cognitive aging. A more promising way to prevent ossification at the helm could be the reallocation of tasks and responsibilities inside the firm and, of course, effective succession planning.

In the last step of the investigation, we ask whether mandatory retirement age limits prevent directors from overstaying, as stipulated by various corporate governance standards, including the report of NACD's Blue Ribbon Commission on Director Professionalism in 2005. Our data cast doubt on the effectiveness of mandatory retirement policies to induce a timely succession plan. We find that COB age is actually higher in firms with mandatory retirement age limits. Moreover, the presence of an age limit does not affect the relation between COB age and firm performance. This finding suggests that the ongoing debate about board retirement policies should be taken with a grain of salt.

Problems such as small sample size, measurement error, insufficient control variables, and simultaneity concerns often plague studies based on surveys. While we are aware of these concerns, we believe that they do not significantly affect the interpretability of our results. First, our investigation is based on more than 1,500 usable questionnaires, more than three times the sample size of recent studies, such as Graham and Harvey (2001) and Brav et al. (2005). Second, the design of the survey should help us to limit the typical sources of measurement error, including satisficing, acquiescence, and social desirability bias (Weisberg, 2005). The following section addresses these issues in detail. We also run Heckman (1979) selection models and find no evidence of non-response bias. Third, the questionnaire itself was quite extensive, which allowed us to collect important control variables such as tenure, firm size, firm age, leverage, and industry, along with information about the firms' ownership structure, board composition, and family affiliation. Finally, we conduct a series of additional tests to address possible concerns 
about endogeneity. In particular, the results are maintained if we control for the possibility that poorly performing firms are more likely to hire older COBs. Moreover, the results do not seem to reflect the inability of poorly performing firms to attract competent successors because we find the same results in a subsample of relatively large and well-performing firms. We recognize, however, that such tests only provide a response to specific endogeneity concerns. Without a valid instrument for $\mathrm{COB}$ age, we are unable to address the problem of endogeneity in general. Therefore, a careful interpretation of our results treats them as correlations instead of causal relations.

The paper proceeds as follows. Section 2 presents our survey in more detail. Section 3 studies the relation between COB age and firm performance. Section 4 asks how cognitive abilities and motivation change as COBs grow older. Section 5 asks whether changes in abilities and motivation help explain the COB age effect. Section 6 concludes.

\section{Survey methodology}

Our data come from a survey conducted in 2007. The questionnaire of 11 pages contained 38 questions and was written in German and French—Switzerland's two major languages. The survey was divided into five sections to collect information on the following: 1) board composition; 2) board compensation; 3) the COB's demographics, preferences, tasks, and responsibilities; 4) ownership structure; and 5) other firm characteristics such as age, industry, and financial performance. ${ }^{1}$ The main advantage of surveys is that they can provide access to valuable information that is commonly unavailable in register data. At the same time, surveybased research is also prone to several biases. According to Weisberg (2005), the three common pitfalls in survey-based research are non-representativeness, measurement error, and survey

A copy of the survey is available from the authors upon request. 
administration issues. We briefly discuss these issues and describe the countermeasures taken when designing the questionnaire, conducting the survey, and analyzing the data.

\subsection{Representativeness: Sample selection, survey, and non-response bias}

To obtain a representative picture of corporate Switzerland, we begin the sample selection procedure with Dun \& Bradstreet's database, which relies on the official Swiss Commercial Register and covers the vast majority of Swiss corporations. Similar to Brounen et al. (2006), we select unlisted firms with more than 25 full-time equivalent employees, sales above CHF 3 million, and at least two directors. This procedure leaves us with 11,875 firms. We eliminate the 2,432 firms that do not have a unique COB to avoid multiple deliveries to the same individual. ${ }^{2}$ The remaining 9,443 firms constitute the population of (relatively large) unlisted Swiss corporations with a unique chairman. We survey the population to avoid sampling error.

A hard copy of the questionnaire was sent in February 2007, along with a pre-stamped envelope and a separate response form to order a free summary report. To increase the response rate, we established a telephone hotline to answer questions related to the survey and resent the questionnaire to all 9,443 COBs in March 2007. A total of 1,514 COBs returned the questionnaire, resulting in a comparatively high response rate of 16.2 percent. $^{3}$

Following Graham and Harvey (2001), among others, we test for non-response bias in several ways. We find the responding firms to be representative in terms of sales, geographic distribution, and general industry classification. This finding holds for the 9,443 firms we initially

2 If successful individuals are more likely to chair multiple companies, this restriction could exclude a disproportionately high fraction of well-performing firms. However, when we compare firms with and without a unique $\mathrm{COB}$, we find no difference in sales, number of employees, and board size, suggesting that our sample is not tilted towards poorly performing firms.

From the 9,443 mailed surveys, 98 were undeliverable and are therefore excluded from the calculation of the response rate. Typical response rates of surveys in North America are 16\% in Brav et al. (2005) and 9\% in Graham and Harvey (2001). In Europe, Brounen et al. (2006) obtained a response rate of 5\%. In Loderer and Waelchli's (2010) survey of Swiss COBs, $21 \%$ have participated. 
targeted, as well as for the broader population of corporate Switzerland as described by the Swiss Federal Statistical Office (except for sales because we filter by sales). Moreover, we compare early and late respondents and find no significant difference in their answers. According to Filion (1975), late respondents are similar to non-respondents. Therefore, we conclude that neither sample selection nor non-response bias significantly affects our investigation and that our sample is representative for unlisted firms in Switzerland.

\subsection{Measurement error}

Another challenge for survey-based research is measurement error. In our investigation, such bias could arise if participants choose not to respond to specific questions or if their response differs from the actual true response, in particular because of satisficing, acquiescence, leading questions, or social desirability. This section focuses on measurement error in actual responses. Item non-response bias is discussed in more detail in the empirical section.

Bias is often induced because wording is not understandable, not universal, or pushes answers one way or another (Weisberg, 2005). To ensure that the wording and survey design are free of such problems, we have developed the questionnaire in close cooperation with a survey expert and a communication specialist, and we have pre-tested the survey extensively with a selected group of representatives from various industries. Furthermore, at the end of the survey, we have asked the participants to identify questions that are difficult to understand. Less than 20 percent of the respondents indicate that there is such a question in the survey. Most of the statements refer to one specific question about the ownership structure, which we therefore exclude from the analysis. In untabulated tests, we also exclude all COBs who indicate that there is an incomprehensible question in the survey. The results do not change. Therefore, we believe that the wording and structure of the questionnaire do not induce systematic bias in responses. 
To counteract satisficing, we enclosed a cover letter in which we introduce the survey team (with pictures and signatures), describe the relevance of the project, and explain how important it is to participate in the survey and how the results will be used (Krosnick et al., 2004). We also perform a series of tests on the actual data, none of which supports satisficing. First, as we will see in more detail below, the typical COB spends a considerable amount of time filling in the survey. This result is inconsistent with satisficing. Second, the results do not change if we drop the 25 percent of respondents with the shortest survey times. These individuals would seem to be particularly prone to satisficing. And third, we find no difference in the item response rate to open questions and choice questions. With satisficing, we would expect respondents to select the first best response from choice questions and to skip open questions.

With respect to acquiescence, Krosnick (1999) argues that bias can be contained by avoiding agree-disagree questions. Therefore, most of our key data are collected with open questions. The exception is a statement about the ultimate target of the company, which we use as a proxy for the COBs' financial orientation. Approximately 20 percent of the respondents declare a commitment to shareholder value maximization. Such a low approval rate is inconsistent with acquiescence. More importantly, the approval rate is in line with Loderer et al. (2010), who collect information about corporate targets from company websites and find that 25 percent of listed Swiss firms express a commitment to shareholder value.

Finally, answers could be biased because of social desirability. This scenario is particularly true if questions address potentially sensitive issues. The literature suggests several procedures to reduce such bias. According to Presser and Stinson (1998), self-administered surveys are less prone to social desirability bias than interviews. Moreover, Ong and Weiss (2000) find that anonymity dramatically reduces the bias. Our survey is both self-administered and anonymous. Finally, as suggested by Presser and Stinson (1998) among others, we administer time-use 
questions instead of direct questions when inquiring about the relevance of the various board tasks - a potentially sensitive issue. Taken together, these measures should help us reduce bias from social desirability.

\subsection{Survey administration issues}

The third source of error stems from survey administration and data processing. In particular, post-survey error could arise because we manually enter the data from the returned questionnaires. Therefore, we double check all data entries. Moreover, coding difference should not be an issue because there are no items with long text answers. Finally, because all data are from the same survey, we do not have to worry about potential mode effects, i.e., the phenomenon that a particular survey administration mode can affect the results that the respondents give.

As in all survey-based research, we are unable to completely rule out survey error. We believe, however, that the careful design and execution of the survey, together with the additional measures described above, minimize potential sources of bias.

\section{COB age and firm performance}

\subsection{Empirical strategy}

In what we refer to as our standard regression, we regress various measures of firm profitability on COB age and a broad range of variables, which should help us control for potential confounding effects:

Profitability $=\mathrm{f}(C O B$ age, $C O B$ tenure, $C E O-C O B$ duality, Board size,

Board independence, Family status, Block ownership, Inside ownership, Firm age, Size, Leverage, Industry). 
It is well-documented that the adverse effects of cognitive aging operate jointly with learning processes. As noted by Korniotis and Kumar (2011), among others, it is important to control for experience when investigating potential age effects. Studying the portfolio positions and investment behavior of more than 60,000 private investors, the authors find that whereas investment skills deteriorate with age, older investors' portfolio decisions reflect greater knowledge about investing. We use the COBs' tenure as a proxy for experience and expect a positive relation with performance.

Because longer tenure could also lead to higher entrenchment (see, among many others, Rose and Shepard, 1997; Yim, 2010), we include additional variables suggested by the literature to capture potential entrenchment effects. In particular, we control for board size (Yermack, 1996; Eisenberg et al., 1998), board independence (Bhagat and Black, 2002), CEO-COB duality (Dalton and Rechner, 1991), family status (Anderson and Reeb, 2003), inside ownership (Morck et al., 1988; Himmelberg et al., 1999) as well as for the presence of blockholders (Holderness, 2003).

Finally, we control for firm age, size, and leverage to disentangle the life cycle of the COB from that of the firm. Loderer et al. (2012) document a strong negative relation between firm age and profitability, which they ascribe to the older firms' inability to generate new growth opportunities. If older COBs are more likely to chair older firms, the negative relation between COB age and performance could in fact reflect more general geriatric problems in older organizations. Similar arguments can be made for firm size (Cooley and Quadrini, 2001) and financial leverage (Jensen, 1986). Together with the industry dummies, financial leverage should also help us control for risk. ${ }^{4}$

4 In later regressions, we will also include the COBs' subjective risk assessment as a further control for risk. The inclusion of this variable does not alter the results, which is why we exclude it from the main investigation. 


\subsection{Descriptive statistics}

Let us now turn to the results of our investigation. Variable definitions are shown in Table 1. Table 2 describes the data and Table 3 shows Pearson correlation coefficients. As shown in the first panel of Table 2, the median (mean) sample firm has CHF 10 (28) million assets, sales of CHF 15 (35) million, a net income of CHF 0.39 (1.36) million, and a debt ratio of 44 (43) percent. At the time of the survey, the CHF traded at an exchange rate of approximately 0.84 USD. Therefore, our firms are somewhat larger than those in other studies of unlisted firms. For example, Bennedsen et al. (2008) report an average book value of assets of approximately USD 3 million for Denmark, and Asker et al. (2011) find an average book value of USD 7 million in the U.S. Because we filter the population of firms by size, this difference is not particularly surprising. Still, when interpreting our results, we must keep in mind that we study relatively large unlisted firms.

\section{[Insert Table 1 about here] \\ [Insert Table 2 about here] \\ [Insert Table 3 about here]}

Our typical sample firm is also quite mature and has been in business for a median number of 43 years. This period is considerably longer than reported in other studies. For example, the median age in the sample of Asker et al. (2011) is 15 years. The difference in age can be ascribed to two factors. First, as we have just mentioned, we survey relatively large unlisted firms. Bartholdy and Mateus (2008) show that age is positively related to firm size, also in unlisted firms. Second, whereas most other studies of unlisted firms measure the age since incorporation, our proxy for age is the number of years since founding. The two proxies for age can differ for various reasons. For example, the incorporation age could be reset to one if a firm changes its 
legal form (e.g., from a limited liability company, LLC, to a corporation), re-incorporates in a different state, or in the case of corporate restructuring (e.g., a statutory consolidation). The difference between the two age proxies can be sizable. A case in point is the Bechtel Corporation, one of the largest private firms in the U.S. According to the company history published on the website, the firm was founded in 1898 and incorporated in the current form in 1945. Therefore, the difference between the founding age and the incorporation age is 47 years. We also consult Worldscope, which contains both founding and incorporation years for 931 listed firms outside the U.S. For Swiss firms, the reported difference between the two age measures is approximately 20 years. Similar numbers result for the full sample.

The second panel of Table 2 shows descriptive statistics for the age of the COBs as well as their tenure in office, our proxy for experience (Vafeas, 2003; Korniotis and Kumar, 2011). The median COB age is 57 years, which is the same as reported in Grinstein and Valles Arellano (2008) for a large sample of S\&P 1500 firms. The median tenure is 14 years, which is slightly higher than what studies in other countries find. There is considerable cross-sectional variation in the two variables, as indicated by a standard deviation of 9.6 and 10.3 years for COB age and tenure, respectively. Taken together, the numbers imply that the typical sample firm has been in business for approximately 30 years before the COB took office. This should help us disentangle the life cycle of the firm from that of its COB.

The third panel summarizes the various performance measures. Our main metrics of firm profitability are return on assets ( $R O A$; mean 7.7 percent; median 5.1 percent) and return on equity (ROE; mean 12.0 percent; median 7.2 percent). For robustness tests, we collect additional performance metrics, namely net profit margin, return per employee, and the sales-to-assets ratio. In terms of profitability, our sample firms are comparable to other studies of unlisted firms that were conducted at approximately the same time. For example, Asker et al. (2011) report an 
average ROA of 7.5 percent for the U.S., and Bartholdy and Mateus (2008) find an average ROA of 7.3 percent in a large sample of unlisted firms from 16 European countries.

Finally, the fourth panel shows the various control variables. In slightly less than 50 percent of the cases, the COB is also the CEO of the firm (bCEO-COB duality). This fraction is much higher than that for listed Swiss firms (20 percent, according to Loderer and Waelchli, 2010). The typical sample firm has four directors (Board size), of which one is independent (Board independence) and one or two are members of the founding family (Family directors). Overall, the board structures of our sample firms seem to be comparable to those in other studies of unlisted firms (e.g., Bennedsen et al., 2008). Our sample firms are also relatively closely held. Typically, the largest shareholder controls 53 percent of the voting rights (vr Largest) and is usually an insider ( $v r$ Executives; median 60 percent). The members of the founding family ( $v r$ Founders; median 42 percent) also play a key role in the ownership structure of unlisted firms. Loderer and Waelchli (2010) report similar ownership structures for larger unlisted Swiss firms. The table also allows us to assess the issue of item non-response and the potential bias it induces. As we have mentioned in the previous section, we have received a total of 1,514 usable questionnaires. However, not all of these questionnaires were filled out in full. The last column of Table 2 shows the item response rate, i.e., the number of usable answers per item divided by the number of returned questionnaires. While the scores for the $\mathrm{COB}$ and board characteristics are very high, respondents seem to be more reluctant to disclose financial data and information about the ownership structure, possibly because they believe this information is confidential. For example, 64 percent of the questionnaires contain information about return on assets $(R O A)$ and 73 percent disclose net profit margin. In untabulated tests, we investigate whether firms that report financial information differ from those that withhold it. We find no differences in COB characteristics. Firm demographics such as age, board structure, and ownership structure are also 
the same. We find, however, than non-reporters tend to be larger in terms of sales and assets and have lower leverage. These firms also seem to be slightly more successful. ${ }^{5}$ Therefore, the item non-response in our dependent variables could tilt our sample towards smaller, less successful firms. In the robustness tests, we will estimate Heckman selection models to address this issue. Moreover, to counteract bias from missing control variables, we add nondisclosure dummies (Himmelberg et al., 1999). The results do not change.

\subsection{Multivariate regressions}

This section studies the relation between COB age and firm performance by estimating the standard regression described in equation (1) above. To account for industry specific differences in firm performance, we include industry fixed effects based on the Industry Classification Benchmark (ICB) provided by Dow Jones and FTSE. ${ }^{6}$ Standard errors are heteroscedasticityconsistent (Huber-White). Table 4 shows the results for our main performance measures $R O A$ (regression 1) and $R O E$ (regression 2), as well as the three additional performance metrics (regressions 3 to 5).

[Insert Table 4 about here]

Performance declines as COBs grow older. The coefficient of $C O B$ age is negative and significantly different from zero in four of the five regressions. An increase in $C O B$ age of one standard deviation (9.6 years) is associated with a decline in $R O A$ of 0.79 percentage points. Given a sample mean $R O A$ of 7.67 percent, this corresponds to a performance decline of 10.3

For example, 163 firms that do not disclose ROA tell us their net profit margin. The average net profit margin of these 163 firms is higher than that of the 947 firms that disclose both net profit margin and ROA (not shown).

6 Our investigation includes 61 firms from the financial industry. The results are qualitatively and quantitatively the same if we exclude these firms. 
percent. ${ }^{7}$ In the case of $R O E$, the decline is approximately 11.5 percent. Similarly, both NPM and ROEMP drop by approximately 9.4 percent if $\mathrm{COB}$ age increases by one standard deviation. Hence, the performance decline in COB age is not dramatic, but it adds up over time. These sensitivities underline the fact that the $\mathrm{COB}$ is a focal player in the organization. Only in regression (5), where the dependent variable is the sales-to-asset ratio, do we find no significant association with $C O B$ age. One possible interpretation could be that firms headed by older COBs do not have lower output as measured by sales, but rather, less efficient cost structures.

To find out more about the functional form of the relation between COB age and firm performance, we estimate piecewise linear regressions that allow for changes in the COB age coefficient at ages 50 and 65 . We choose age 50 as the lower turning point because, according to Verhaegen and Salthouse (1997), job performance begins to deteriorate after age 49. The upper turning point of 65 years denotes the official retirement age in Switzerland. Therefore, to implement the piecewise approach, we replace $C O B$ age with the following three variables in our regression:

$$
\begin{array}{rl}
C O B \text { age }<50 & C O B \text { age if } C O B \text { age }<50 \\
= & 49 \text { if } C O B \text { age } \geq 50 \\
50 \leq C O B \text { age }<65= & 0 \text { if } C O B \text { age }<50 \\
= & (C O B \text { age }-49) \text { if } 50 \leq C O B \text { age }<65 \\
= & 15 \text { if } C O B \text { age } \geq 65 \\
= & 0 \text { if } C O B \text { age }<65 \\
& (C O B \text { age-64) if } C O B \text { age } \geq 65
\end{array}
$$

If, for instance, the COB age is $68, C O B$ age $<50$ takes a value of $49,50 \leq C O B$ age $<65$ is 15 , and $65 \leq C O B$ age is 4 . The results of the piecewise linear regressions are shown in Table 5 . Accordingly, COB age is unrelated to firm performance until age 50. Thereafter, and consistent with previous literature, performance slips as COBs grow older. $R O A$, for example, drops by 0.13

7 To facilitate the interpretation of our results, the second argument in the parentheses below the regression coefficients reports such sensitivity measures for all significant coefficients. 
percentage points for each additional year of $\mathrm{COB}$ age. Again, the effect is not dramatic, but it cumulates. If we measure the impact of a one-standard-deviation change of $\mathrm{COB}$ age around its mean (from age 49 to 65 ), $R O A$ declines by 14.9 percent. After COB age 65 , performance seems to bottom out (ROA and ROE) or even rebound slightly (NPM and ROEMP). Presumably, COBs can step down without losing face when they reach the official retirement age. It looks as if underperforming COBs are more likely to exercise this exit option. However, because of the relatively few observations at the far end of the $\mathrm{COB}$ age distribution, the coefficient of $65 \leq C O B$ age should be interpreted with caution.

\section{[Insert Table 5 about here.]}

Finally, we also estimate non-parametric kernel regressions. To preserve space, Figure 1 only reports the results for our two main performance measures, $R O A$ and $R O E$. The graphical illustration confirms the functional form of the age-performance relation from the piecewise linear regressions. For reading convenience, we switch back to the linear age measure for the remaining investigation. To avoid clutter, we only report the results for $R O A$. The results for $R O E, N P M$, and $R O E M P$ are qualitatively the same throughout the analysis.

[Insert Fig. 1 about here.]

Before inquiring into the robustness of the results, let us briefly turn to the control variables in our standard regression. Contrary to our predictions, $C O B$ tenure is statistically zero in all regressions. Therefore, more extensive experience does not seem to increase performance, on average. Older firms generally exhibit poorer performance, which is consistent with Loderer et al.'s (2012) findings for the U.S. Board size, and Board independence have generally negative but insignificant coefficients. ${ }^{8}$ The same result is true of $v r$ Founders and $v r$ Executives. We find,

8 In untabulated tests, we follow Bennedsen et al. (2008) and identify boards with more than 6 members. In line with their results, we find that firms with board sizes larger than 6 are significantly less profitable, whereas board sizes below 6 are unrelated to profitability. The coefficient of $C O B$ age remains the same. 
however, that the $R O A$ of firms with CEO-COB duality is approximately 1 percentage point (15.6 percent) lower than for firms that split the role. In untabulated regressions, we interact $b C E O$ $C O B$ duality with all control variables to find out to what extent the CEO-COB effect could be driven by differences in firm characteristics. In that regression, $b C E O-C O B$ duality is statistically zero, indicating that duality per se is not associated with lower profitability. More importantly, $C O B$ age maintains its negative and significant coefficient.

With respect to the fraction of family directors on the board, we find a negative relation with profitability. Accordingly, an increase of Family directors by one standard deviation is associated with a drop in $R O A$ of 8 percent. Along similar lines, Bennedsen et al. (2008) find that firms with large families that appoint many directors exhibit poorer performance. We find a positive association between $v r$ Largest and profitability, suggesting that large shareholders are an important governance mechanism in unlisted firms. Finally, the coefficients of Size and Leverage are in line with previous literature. Large firms exhibit lower profitability (Cooley and Quadrini, 2001). More specifically, an increase in Size of one standard deviation is associated with a decline in ROA of 5.6 percent. $R O E$ and Sales to asset behave similarly, whereas larger firms have higher NPM and ROEMP, possibly because of economies of scale. Higher leverage reduces overall profitability ( $R O A, R O E M P$, Sales to asset), possibly because of frictions induced by financial constraints (see also Brav, 2009). Higher leverage is also associated with a lower profit margin but increases the shareholders' required rate of return.

\subsection{Robustness tests}

\subsubsection{Listing status}

Previous studies, most of which have been conducted for listed U.S. firms, document that the demographics of individual managers, typically the CEO, can affect corporate policy (see, for 
example, Bertrand and Schoar, 2003; Yim, 2010; Li et al., 2011; however, see also Fee et al., 2011). Individual age, however, seems to be unrelated to profitability in listed firms (Bhagat et al., 2010). This finding raises the question of how the negative relation between COB age and profitability documented in this paper can be interpreted. Is this relation a genuinely Swiss effect or could it be the result of much weaker formal governance rules in unlisted firms?

To shed some light on this question, we re-estimate our standard regression from Table 4 for a control sample of 197 listed Swiss firms in 2006, the year to which the financial data in our survey refer. ${ }^{9}$ In untabulated regressions, we find no relation between $\mathrm{COB}$ age and firm performance, regardless of how we measure profitability. Neither is an extended panel that covers all listed Swiss firms over the period 1995 to 2009 able to produce a significant relation between COB age and firm performance. Possibly, the relatively strict rules that govern listed Swiss firms provide sufficient monitoring of the monitor and prevent COBs from overstaying, as seems to be the case in other countries. Therefore, the results of our investigation apply to unlisted firms. Studies of unlisted firms in other countries also report a negative correlation between individual age, typically that of the CEO, and profitability. ${ }^{10}$

\subsubsection{Owner-managed firms}

A firm that is fully controlled by insiders need not necessarily focus on financial profitability to foster shareholder value. Instead, the owner-managers could consume private benefits of control such as excessive salaries, quiet lives, or other perks, including company resources for private use. ${ }^{11}$ Therefore, declining profitability metrics do not necessarily imply that shareholders are

\footnotetext{
Most board and ownership data are from Waelchli (2009). We update the information on director age, board composition, and ownership structure. Financial data are from Compustat Global.

For example Bennedsen et al. (2008) for Denmark.

Because of the double taxation of dividend payments, such behavior could constitute a tax-efficient way to extract cash from the firm.
} 
worse off. If older COBs are more likely to be such owner-managers, what looks like a decline in performance could actually be a tax-efficient way to disseminate shareholder value. It is difficult to believe, however, that this tax argument can be extended to firms with a relatively dispersed ownership structure because (external) minority shareholders typically have no direct access to the company's resources.

In regression (1) of Table 6, we therefore extend our standard regression with an indicator variable that equals 1 if the minority shareholders together own less than 10 percent of the voting rights (bClosely held), as well as an interaction term of this indicator with $C O B$ age. The coefficients of both variables are statistically zero, indicating that the age-related decline in profitability is not restricted to very closely held firms. The same results obtain when we identify firms in which minority shareholders together control up to 50 percent of the shares (bMajority shareholder) and interact this indicator with $C O B$ age. In fact, the coefficient of that interaction term is positive and significant, suggesting that the age-related performance decline is actually stronger in firms with significant minority shareholders. This result is in line with the predictions from standard agency theory. The reduced monitoring function of minority shareholders seems to aggravate the detection and removal of underperforming managers. It could also be that a dispersed ownership structure invites COBs to consume more private benefits of control because they must bear a smaller fraction of the associated costs. In either case, overstaying COBs seem to posit a real agency problem in unlisted firms.

[Insert Table 6 about here.]

\subsubsection{The old guard and the superstars}

To the extent that CEOs retire to the chairmanship (Brickley et al., 1997; Brickley et al. 1999; Fahlenbrach et al., 2011), they might maintain a significant amount of control over the firm's 
activities and thereby undermine the authority of the new CEO. Hence, what looks like a negative relation between $\mathrm{COB}$ age and performance could actually be the result of governance voids caused by members of the old guard who are reluctant to hand over the reins.

Under this alternative hypothesis, we would expect firms with CEO-COB duality to outperform firms with a dual leadership structure. As we have seen in the discussion of the control variables in Tables 4 and 5, this does not seem to be the case. The effect of CEO-COB duality on profitability is statistically zero once we add interaction terms to allow for differences in the control variables. In that regression, the interaction term of $b C E O-C O B$ duality and $C O B$ age is insignificant. This finding suggests that the $\mathrm{COB}$ age-performance relation is not driven by firms with a dual leadership structure (not shown).

Similar arguments could be made for founders who fail to relinquish full control to their successors. However, as we have mentioned above, our typical sample firm has been in business for approximately 30 years before the current $\mathrm{COB}$ took office. Hence, the typical $\mathrm{COB}$ is not the founder of the company. It turns out that only 22 percent of the COBs have been involved with the company from its inception and could, therefore, be classified as founders. To find out whether these founders drive our results, we identify them with a dummy variable and add an interaction term with $C O B$ age. The coefficients of the additional variables are insignificant. Therefore, it is difficult to believe that members of the old guard are the driving force behind the negative relation between $\mathrm{COB}$ age and performance.

Finally, one could also argue that because there is considerable cross-sectional variation in abilities, the age at which a COB takes office could be a proxy for talent. If particularly talented individuals are appointed $\mathrm{COB}$ at a relatively young age, the negative relation between $\mathrm{COB}$ age and performance could reflect such differences in talent. To test this alternative interpretation, we follow Korniotis and Kumar (2011) and sort our sample by the age at which the COB took office. 
We then re-estimate our standard regression for the sub-samples of firms with relatively low and relatively high COB appointment age, respectively. The COB age effect is statistically the same in the two sub-samples (not shown). Therefore, our results do not seem to be driven by superstar COBs who are appointed at young age.

\subsubsection{Sample selection and non-disclosure}

We have seen in Table 2 that approximately one third of the returned questionnaires contain no information about our main performance measures. To assess whether this could bias our results, we estimate a two-step Heckman (1979) selection model. In the survey, we have asked the participants whether there are questions that touch on confidential issues (bConfidential). Of the 1,350 answers we receive to this question, 43 percent are affirmative. Because confidentiality concerns would seem to reduce the willingness to disclose information, we use bConfidential as our selection variable.

\section{Table 7}

Sample selection shows the results of the selection model. To preserve space, we only report the coefficients of the main variables. The first step regression shows that $b$ Confidential is associated with significantly lower survey item participation. In the second step, $C O B$ age is still negative and significant, regardless of profitability measure. More importantly, for both the $R O A$ and $R O E$ regression, the inverse mills ratio is statistically zero, indicating that our selection model is unable to detect selection bias.

\section{[Insert Table 7}

Sample selection about here.]

In untabulated regressions, we also include nondisclosure dummies for control variables with low item response rates (in particular, the firm's ownership structure). This increases the 
sample size of the ROA regression by more than 30 percent to 919 observations. The results do not change. Moreover, all nondisclosure dummies are statistically zero.

Taken together, these results indicate that neither sample selection nor item non-response seem to add a severe bias to our investigation. In what follows, we will therefore continue to use our standard regression.

\subsubsection{Endogeneity}

Obviously, endogeneity concerns resulting from omitted variables, simultaneity, and measurement error are difficult to rule out in our investigation. In particular, an open issue is whether we can interpret our results as simple correlations or as causal relations.

Econometrically, there is little we can do to address these concerns. Economically, however, we find it difficult to believe that the physical age of the $\mathrm{COB}$ could be driven by the profitability of the firm in a way that could explain our results. For poor performance to increase COB age, one would have to posit that poor performance reduces the turnover probability, which is rejected by the extant evidence (see, for example, Brickley, 2003), also for Switzerland (Waelchli, 2009). Alternatively, one would have to assume that poorly performing firms are more likely to hire older COBs, whereas well-performing firms are more likely to attract younger COBs. If that were true, we would expect poorly performing firms to be chaired by older COBs with relatively short tenure.

The data do not support this proposition. In a univariate analysis, COB age and tenure are positively correlated in a sub-sample of poorly performing firms (not shown). Moreover, we identify all COBs with tenure of less than 5 years $($ bTenure $<5)$ and interact this dummy variable with $C O B$ age in our standard regression. It is difficult to believe that the poor performance that could have led to the appointment of an older COB remains visible in the data five years after the 
COB took over. Therefore, under the alternative hypothesis that poorly performing firms attract older COBs, we would expect the interaction term to pick up the COB age effect, but that is not the case. As shown in regression (4) of Table 6, the coefficients of the indicator variable and the interaction term are both insignificant, whereas $C O B$ age maintains its significantly negative coefficient.

An alternative hypothesis of reverse causality could be that relatively small and poorly performing family firms are unable to attract competent outside successors. ${ }^{12}$ Therefore, the incumbent team either stays in office or opts for a family succession, which could induce the owner-manager to stay longer. While this argument seems plausible, we believe that it does not fully explain our results. First, remember from the robustness tests that our results do not change if we control for the presence of founders. Therefore, the age effect per se does not seem to be driven by founders who fail to relinquish control. Second, in untabulated regressions, we constrain the sample to relatively large (Size above the sample median) and well-performing ( $R O A$ above the sample median) firms. Such firms would seem to be relatively attractive employers, also for outside successors. In this subsample, $C O B$ age still takes on a negative and significant coefficient, regardless of whether we control for the presence of founders.

Such tests allow us to address the concerns about specific manifestations of endogeneity. In principle, instrumental variable regressions would offer a more general way to address this issue. However, to the best of our knowledge, the relevant literature has not identified a valid instrument for age. In fact, many finance papers that report age-induced differences in behavior do not directly address endogeneity. Without a valid instrument, we are unable to estimate instrumental variable regressions. Therefore, a careful interpretation of our results treats them as correlations instead of causal relations.

12 We are grateful to the anonymous referee for pointing this out to us. 


\section{Age-related changes in abilities and motivation}

Aging is a manifold collection of changes that render human beings progressively more likely to die (Medawar, 1952). Of the many physical, psychological, and social changes that are associated with aging, the declining cognitive abilities and shifting preferences of older individuals seem to be particularly relevant to our investigation.

\section{1. $C O B$ age and cognitive abilities}

According to Verhaeghen and Salthouse (1997), the cognitive abilities such as efficiency and effectiveness of information processing (e.g., speed, reasoning and memory) begin to decline before age 50, on average, and deteriorate progressively thereafter. Executive functions seem particularly prone to aging effects (see, for example, Rhodes, 2004). Consistent with that finding, Taylor (1975) documents that managerial decision-making performance declines with age.

To measure the COBs' cognitive abilities, we use a speed proxy as well as the self-reported perception of job complexity. The concept of speed is well established in the literature and considered the strongest predictor of age-related declines in cognitive abilities currently available, according to Verhaegen and Salthouse (1997) and Park and Reuter-Lorenz (2009), among others. Because slowing is task-independent (Birren and Fisher, 1995), a broad range of speed measures can proxy for cognitive abilities. Our speed measure is the (self-reported) time in minutes that the COBs took to fill in the questionnaire (Survey time). We have also asked the COBs to assess the complexity of their tasks (Complexity). We use this variable as an alternative proxy for cognitive abilities. It is indicated on a 5-point Likert scale, with 1 being the lowest and 5 the highest level of complexity. Descriptive statistics of the two variables are shown in Table 
8a. Table $8 \mathrm{~b}$ reports the results of multivariate regressions of the two variables on $C O B$ age and the standard set of control variables.

[Insert Table 8 about here.]

In line with the predictions from previous literature, speed significantly decreases as COBs grow older. According to regression (1), an increase in $C O B$ age of one standard deviation is associated with a Survey time that is 2.3 minutes longer. Given a sample mean of 21.6 minutes, this corresponds to a time increase of approximately 11 percent. More importantly, the piecewise linear regression (2) reveals that the largest change in speed occurs between ages 50 and 65 , which is consistent with the extant literature. The regressions for Complexity, our alternative proxy for cognitive abilities, corroborate these findings. Older COBs are significantly more likely to concede that job complexity has increased in recent years - and the main effect again takes place between ages 50 and 65 years. This finding is consistent with Rhodes (2004), who documents that individuals find it increasingly difficult to execute complex tasks as they grow older. ${ }^{13}$ Taken together, and consistent with the extant literature, we conclude that the cognitive abilities of our COBs decrease significantly as they grow older.

\section{2. $C O B$ age and motivation}

Aging also seems to affect an individual's motivation. Ebner et al. (2006) report that younger individuals are more likely to strive for gains, whereas older individuals tend to maintain the status quo and aim at preventing loss. This pattern finds support in the finance literature, according to which younger CEOs pursue more acquisitions (Yim, 2010) and invest more aggressively than their older peers (Li et al., 2011). Moreover, Ferris et al. (2003) argue that older does not seem to be driven by the older COBs' more extensive job experience or better ability to make intertemporal comparisons. 
directors are prone to last-period problems such as the reluctance to update their skills and a reduced willingness to work hard (Jagannathan and Loon, 2011). Based on this literature, we hypothesize a negative relation between the age of the COB and her job performance.

To assess whether the COBs' motivation changes as they grow older, we use various proxies for business objectives, job activities, and compensation.

\subsubsection{Business objectives}

We have asked the COBs to specify which ultimate goal they pursue with their activities. Specifically, they could indicate on a Likert scale from 1 to 5 whether they believed that the interests of the shareholders were more important than those of the other stakeholders. Previous studies find that older individuals are less driven by money (Ebner et al., 2006) and more strongly committed to organizational citizenship behavior (Ng and Feldman, 2008). Accordingly, we would expect older COBs to shift away from shareholder value to a broader corporate target that embraces all stakeholders.

This prediction is supported by the data. The descriptive statistics in Table 9a show that, with a mean score of 1.8 out of 5 , the typical COB only expresses a lukewarm commitment to shareholder value. In the multivariate framework reported in Table 9b, $C O B$ age takes on a significantly negative coefficient, indicating that shareholder value maximization becomes less important as COBs grow older.

[Insert Table 9 about here.]

\subsubsection{Job activities}

Job activities also seem to shift with age. In particular, according to $\mathrm{Ng}$ and Feldman (2008) among others, older individuals prefer clearly defined tasks over less-structured activities. 
Moreover, they seem to favor the status quo (Ebner et al., 2006), are more resistant to change (Cornelis et al., 2009), and have fewer career concerns (Li et al., 2011).

To find out whether job activities change as COBs grow older, we have asked them to indicate the actual amount of time (in percent) as well as the subjective optimal amount of time (in percent) they spend on the following activities: 1) strategic tasks; 2) monitoring; 3 ) controlling, reporting, and auditing; 4) interaction with business partners; and 5) other activities, which they could freely list. If older COBs prefer more-structured activities, we would expect them to shift from strategic tasks to controlling, reporting, and auditing activities.

Table 9c describes the data. As one would expect, COBs spend most of their time on controlling, reporting, and auditing (28 percent), monitoring activities (28 percent), and strategic tasks (27 percent). Interestingly, according to the last column of the table, there are some notable differences between the actual and the target time allocation. In particular, COBs, on average, would prefer to spend significantly more time on the firm's strategy and significantly less time on monitoring and financial planning.

To find out whether the activities and job preferences change as COBs grow older, we estimate a multivariate fractional logit model with a quasi-maximum likelihood estimator, as proposed by Papke and Wooldridge (1996). ${ }^{14}$ The results in Table 9d are generally in line with our predictions. Each row of the table reports the coefficients from a separate regression of the time allocated to a specific task on $C O B$ age, $C O B$ tenure, and our standard set of control variables (including industry fixed effects). For reading convenience, we only report the coefficients of $C O B$ age and $C O B$ tenure. The left (right) part of the table refers to the actual (target) time allocation. results remain qualitatively the same if we estimate a fractional multinomial logit model to account for the fact that, by construction, the time proportions allocated to the various tasks are negatively correlated. 
With respect to the COBs' actual activities, we find that the time spent on controlling, reporting, and auditing increases significantly with age, which is consistent with the increased safety performance of older individuals. Moreover, older COBs spend more time on 'other activities.' Popular other activities are 'alumni reunion', 'art and culture', 'colleagues and friends', 'use of fleet', and 'visit expositions' — most of which seem to be indicators of quiet life.

It is important to note that the same age-related differences obtain if we look at the target time allocation. Hence, older COBs actually prefer to spend more time on 'bureaucratic' tasks and other activities. Moreover, the coefficient of $C O B$ age is borderline significant (p-value of 0.102) in the regression involving the target time allocation to strategic tasks. Because strategic initiatives can be disruptive to the organization and its products and processes, this result could indicate the higher resistance to change of older COBs.

\subsection{3. $C O B$ age and compensation}

Finally, we take a brief look at the compensation packages of COBs. According to Adams et al. (2010), financial incentives are important in the board room. We have asked the COBs whether they participate in an incentive plan (bVariable compensation) and whether they would prefer a more performance-sensitive compensation (Higher incentives). Descriptive statistics are reported in Table 9a. Only 19 percent of the COBs receive variable compensation. ${ }^{15}$ Moreover, the typical COB does not seem to prefer a more performance-sensitive compensation plan.

Table 9b takes the COBs' compensation packages to the multivariate framework and asks whether the actual and the desired structure of the compensation are related to the age of the COB. According to regression (2), older COBs are significantly less likely to receive variable compensation. At the mean, an increase in $C O B$ age of one standard deviation reduces the

15 For the average COB with an incentive plan, approximately 48 percent of total compensation depends on firm performance (not shown). 
probability of receiving variable pay by approximately 5 percentage points (from 19 to 14 percent). Hence, firms do not seem to increase the performance sensitivity of compensation to counteract potential last period problems of older COBs (see, among others, Ferris et al., 2003; Jagannathan and Loon, 2011). Moreover, as regression (3) shows, the desire for variable compensation also declines as COBs age.

An alternative interpretation could be that older COBs are more risk-averse and, therefore, request more stable compensation packages (Morin and Fernandez Suarez, 1983). To shed some light on the COBs' risk assessment and whether it drives compensation preferences, we have asked the COBs whether they believed that being a director has become riskier in recent years (bRisk perception). 81 percent of the respondents agree with this statement. When we add bRisk perception to the regression, $C O B$ age remains negative and significant (regression 4). Interestingly, and contrary to the presumption of risk-averse COBs, the coefficient of bRisk perception is positive and significant with confidence 0.9 , indicating that COBs actually want to participate financially in the risks they take. Adding an interaction term of bRisk perception and $C O B$ age does not alter this result (not shown). We conclude that risk affects the compensation that COBs desire, but cannot explain the negative relation between age and performance.

Taken together, this section documents significant age-related shifts in cognitive abilities, business objectives, job activities, and compensation packages. Our COBs seem to age much like 'ordinary' people. Because cognitive abilities and motivation are shown to drive job performance (Salthouse, 2012), the following section asks whether these channels are responsible for the COB age effect that we observe. 


\section{What drives the relation between $\mathrm{COB}$ age and firm performance?}

\subsection{Results}

To find out whether changes in cognitive abilities and motivation help explain the COB age effect, we extend our standard performance regression with the proxies presented in the previous section. The results are shown in Table 10. For reading convenience, regression (1) repeats the coefficients from our standard regression in Table 4. When we add Survey time, our main measure of cognitive abilities (regression 2), the coefficient of $C O B$ age declines in magnitude and significance. Instead, Survey time takes on a negative and highly significant coefficient, suggesting that much of the $\mathrm{COB}$ age effect we observe can be ascribed to a decline in cognitive abilities.

\section{[Insert Table 10 about here.]}

The changes in motivation can also help explain parts of the COB age effect that we observe. We find that COBs whose business objective is to foster shareholder value are associated with higher profitability (regression 3). This result is in line with Loderer et al. (2010), who document that firms walk the talk in regard to commitments to shareholder value maximization. The time that COBs spend on the various tasks has no impact on performance, according to regression (4). ${ }^{16}$ In addition, the presence of a COB with a preference for more performance sensitivity in compensation leaves profitability unaffected (regression 5). Note that in all three regressions involving the proxies for motivation, the coefficient of $C O B$ age remains negative and significant. Finally, regression (6) includes all five proxies for cognitive abilities and motivation. The results are the same as in the individual regressions. The main change we observe is that the coefficient of $C O B$ age is still negative, but no longer significant. This finding

16 The correlation coefficient between the time spent on strategic tasks and the time spent on controlling, reporting, and auditing is -0.22 . Hence, multicollinearity does not seem to be a major concern when including these two variables in the same regression. 
implies that when viewed together, changes in cognitive ability and motivation seem to fully explain the $\mathrm{COB}$ age effect. The coefficients and significance levels of various proxies are the same as in the individual regressions (2) to (5). Therefore, multicollinearity does not seem to be a major concern.

\subsection{Discussion}

The unique survey data allow us to open the black box of aging agents and their impact on performance. Of the various age-related changes we document for the COBs of unlisted firms, cognitive aging and, to a lesser extent, reduced focus on shareholder value are relevant for performance. This finding seems relevant for both academia and practice. First, there is a growing literature in finance that relates the individual characteristics of managers to firm policy and performance. Many of these studies control for individual age. Our results confirm that the age of the $\mathrm{COB}$ is an important dimension and that $\mathrm{COB}$ age is significantly related to firm performance in unlisted firms. Second, of the many things that age can represent, we show that, at the corporate helm, age essentially reflects cognitive abilities. This result contributes to a better understanding of existing findings in the literature, for example with respect to reported differences in investment (Korniotis and Kumar, 2011) and acquisition (Yim, 2010) behavior. Understanding the source of the age effect is also important when trying to find a possible remedy. Cognitive aging cannot be cured with compensation packages or stricter monitoring. A more promising approach could be the reallocation of tasks and responsibilities inside the firm and, of course, an effective succession plan. In this regard, our results suggest that unlisted firms may have a fundamental governance problem, when they do not prevent their COB from overstaying. In fact, inert retirement policies in corporate boards have attracted considerable attention from shareholder activists, policy makers, and the popular press. Various codes of best 
practice around the world require that firms enforce a mandatory retirement age to prevent directors from overstaying. ${ }^{17}$

Our results cast doubt on the effectiveness of such policies. It is difficult to believe that enforcing a strict retirement age or limiting tenure can prevent the performance decline we observe. As we have seen, aging is a gradual process that sets in relatively early but also has considerable cross-sectional variation. Therefore, a general age limit appears to be an inefficient mechanism to prevent $\mathrm{COBs}$ from overstaying. A more promising approach could be to have key agents undergo routine tests of their physical and mental fitness to fulfill their tasks - similar to the tests that pilots must undergo to maintain their rating.

In fact, setting a mandatory retirement age could actually be counterproductive. As we have seen, the kink in the age-performance relation near age 65 suggests that the official retirement age of 65 offers aging COBs a face-saving exit option. In practice, firms often set the mandatory retirement age at 70 or older, which could dilute the attractiveness of the 'official' exit option and induce COBs to stay longer.

\section{[Insert Table 11 about here.]}

Tentative evidence is unable to reject this conjecture. We have asked the COBs whether their position is subject to any age restrictions (bAge limit). As it turns out, only 19 percent of our sample firms set a maximum retirement age. According to Table 11a, COB age is slightly higher, on average (57.7 vs. 56.5 years), whereas Survey time, our proxy for cognitive abilities, is statistically the same in both sub-samples. ${ }^{18}$ In regression (1) of Table $11 \mathrm{~b}$, we extend the standard performance model with bAge limit as well as an interaction term of bAge limit and

The NACD's Blue Ribbon Commission on Director Professionalism (2005), for example, states that "the board should establish procedures for the retirement or replacement of board members. These procedures may, for example, include a mandatory retirement age [...]." restrictions. 
$C O B$ age. The coefficients of both additional variables are statistically zero, whereas $C O B$ age maintains its sign and significance. When we add Survey time, the coefficient of $C O B$ age again declines in magnitude and significance (regression 2). More importantly, bAge limit and the interaction term are unaffected by the inclusion of this variable. Setting a mandatory retirement age, therefore, does not seem to help firms overcome the problems associated with aging COBs. A more thorough analysis of the unlisted firms' apparent succession planning problem must be left open for future research.

\section{Conclusion}

Around the world, life expectancy has been increasing for decades and so has the median age of the working population. A large body of literature in economics, psychology, and sociology examines the challenges posed by this demographic change. Recently, the finance literature has jumped the bandwagon by investigating, among other things, how investment and financing decisions are related to the physical age of the CEO. This paper takes the issue to the board room of unlisted firms, the backbone of every economy. We want to know whether aging COBs affect firm performance, and if so, why that could be the case. The data come from a recent survey of almost 10,000 COBs of unlisted Swiss firms. The resulting sample is representative of corporate Switzerland in various ways.

We find a statistically and economically significant negative relation between $\mathrm{COB}$ age and various measures of firm profitability. The deleterious effect of age begins at approximately 50 years. COBs, on average, manage to impose their own life cycle on the firms they lead. Moreover, and consistent with standard agency theory, the age effect is stronger in firms with significant minority shareholders. To the best of our knowledge, we are the first to document such a COB age effect. The dataset allows us to take the analysis one step further and crack open 
the black box surrounding 'aging.' Previous literature finds that cognitive abilities and motivation are two of the main age-related determinants of job performance. Consistent with this literature, we show that older COBs are significantly slower and experience substantial shifts in motivation. COBs seem to age much like 'ordinary' people do.

Finally, we ask whether the changes in abilities and motivation help explain the age effect we observe. The negative relation between $\mathrm{COB}$ age and firm performance is mainly driven by the deterioration of the captain's cognitive abilities. Motivation also seems to play a role, but its effect is considerably smaller.

Taken together, our results suggest that unlisted firms could have a problem with succession planning. Various codes of best practice stipulate mandatory retirement age limits to prevent directors from overstaying. Tentative evidence casts doubts on the effectiveness of this simple remedy. If anything, the COB age is higher in firms with such clauses. Moreover, the presence of board age limits leaves the relation between $\mathrm{COB}$ age and firm performance unaffected. This result implies that the ongoing debate on board retirement policies should be taken with a grain of salt.

\section{Acknowledgements}

A large portion of this research has been conducted during Waelchli's visit at Purdue University. Our special thanks go to the 1,514 chairmen and chairwomen who have participated in this survey. We wish to thank Ike Manur (the editor) and an anonymous referee for the great criticism and suggestions. Comments from Stefan Aebischer, Demian Berchtold, Claudio Loderer (especially), David Oesch, Urs Peyer, Markus Senn, participants of the First Macro Uni Bern Conference, and the 15th SGF Conference are gratefully acknowledged. 


\section{References}

Adams, R.B., Hermalin, B.E., Weisbach, M.S., 2010. The role of boards of directors in corporate governance: A conceptual framework and survey. Journal of Economic Literature 48, 58107.

Anderson, R.C., Reeb, D.M., 2003. Founding-family ownership and firm performance: Evidence from the S\&P 500. Journal of Finance 58, 1301-1328.

Asker, J., Farre-Mensa, J., Ljungqvist, A., 2011. Comparing the investment behavior of public and private firms. Working paper, New York University.

Bartholdy, J., Mateus, C., 2008. Taxes and corporate debt policy: Evidence from sixteen European countries. Working paper, Aarhus School of Business.

Bennedsen, M., Kongsted, H.C., Nielsen, K.M., 2008. The causal effect of board size in the performance of small and medium-sized firms. Journal of Banking and Finance 32, 10981109.

Bertrand, M., Mullainathan, S., 2003. Enjoying the quiet life? Corporate governance and managerial preferences. Journal of Political Economy 111, 1043-1075.

Bertrand, M., Schoar, A., 2003. Managing with style: The effect of managers on firm policies. Quarterly Journal of Economics 118, 1169-1208.

Bhagat, S., Bolton, B., Subramanian, A., 2010. CEO education, CEO turnover, and firm performance. Working paper, University of Colorado at Boulder.

Bhagat, S., Black, B.S., 2002. The non-correlation between board independence and long-term firm performance. Journal of Corporation Law 27, 231-273.

Birren, J.E., Fisher, L.M., 1995. Aging and speed of behavior: Possible consequences for psychological functioning. Annual Review of Psychology 46, 329-353.

Booth, J.R., Cornett, M.M., Tehranian, H., 2002. Boards of directors, ownership, and regulation. Journal of Banking and Finance 26, 1973-1996.

Brav, A., Graham, J.R., Harvey, C.R., Michaely, R., 2005. Payout policy in the $21^{\text {st }}$ century. Journal of Financial Economics 77, 483-527.

Brav, O., 2009. Access to capital, capital structure, and the funding of the firm. Journal of Finance 64, 263-308.

Brickley, J.A., 2003. Empirical research on CEO turnover and firm-performance: A discussion. Journal of Accounting and Economics 36, 227-233. 
Brickley, J.A., Coles, J.L., Jarrell, G., 1997. Leadership structure: Separating the CEO and chairman of the board. Journal of Corporate Finance 3, 189-220.

Brickley, J.A., Linck, J.S., Coles, J.L., 1999. What happens to CEOs after they retire? New evidence on career concerns, horizon problems, and CEO incentives. Journal of Financial Economics 52, 341-377.

Brounen, D., de Jong, A., Koedijk, K., 2006. Capital structure policies in Europe: Survey evidence. Journal of Banking and Finance 30, 1409-1442.

Cooley, T.F., Quadrini, V., 2001. Financial markets and firm dynamics. American Economic Review 91, 1286-1310.

Cornelis, I., Van Hiel, A., Roets, A., Kossowska, M., 2009. Age differences in conservatism: Evidence on the mediating effects of personality and cognitive style. Journal of Personality 77, 51-88.

Dahya, J., McConnell, J.J., Travlos, N.G., 2002. The Cadbury Committee, corporate performance, and top management turnover. Journal of Finance 57, 461-483.

Dalton, D.R., Rechner, P.L., 1991. CEO duality and organizational performance: A longitudinal analysis. Strategic Management Journal 12, 155-160.

Ebner, N.C., Freund, A.M., Baltes, P.B., 2006. Developmental changes in personal goal orientation from young to late adulthood: From striving for gains to maintenance and prevention of losses. Psychology and Aging 21, 664-678.

Eisenberg, T., Sundgren, S., Wells, M.T., 1998. Larger board size and decreasing firm value in small firms. Journal of Financial Economics 48, 35-54.

Fahlenbrach, R., Minton, B., Pan, C.H., 2011. Former CEO directors: Lingering CEOs or valuable resources? Review of Financial Studies 24, 3486-3518.

Fee, C.E., Hadlock, C.J., Pierce, J.R., 2011. Managers who lack style: Evidence from exogenous CEO changes. Working paper, Michigan State University.

Ferris, S.P., Jagannathan, M., Pritchard, A.C., 2003. Too busy to mind the business? Monitoring by directors with multiple board appointments. Journal of Finance 58, 1087-1111.

Filion, F.L., 1975. Estimating bias to nonresponse in mail surveys. Public Opinion Quarterly 39, 482-492.

Florou, A., 2005. Top director shake-up: The link between chairman and CEO dismissal in the UK. Journal of Business Finance and Accounting 32, 97-128.

Graham, J.R., Harvey, C.R., 2001. The theory and practice of corporate finance: Evidence from the field. Journal of Financial Economics 60, 187-243. 
Grinstein, Y., Valles Arellano, Y., 2008. Separating the CEO from the chairman position:

Determinants of changes after the new corporate governance regulation. Working paper, Cornell University.

Heckman, J.J., 1979. Sample selection bias as a specification error. Econometrica 47, 153-161.

Himmelberg, C.P., Hubbard, R.G., Palia, D., 1999. Understanding the determinants of managerial ownership and the link between ownership and performance. Journal of Financial Economics 53, 353-384.

Holderness, C.G., 2003. A survey of blockholders and corporate control. Economic Policy Review 9, 51-63.

Jagannathan, M., Loon, Y.C., 2011. Mandatory retirement policies for CEOs. Working paper, SUNY Binghampton.

Jensen, M.C., 1986. Agency costs of free cash flow, corporate finance, and takeovers. The American Economic Review 76, 323-329.

Kim, E.H., Lu, Y., 2011. CEO ownership, external governance, and risk-taking. Journal of Financial Economics 102, 272-292.

Korniotis, G.M, Kumar, A., 2011. Do older investors make better investment decisions? Review of Economics and Statistics 93, 244-265.

Krosnick, J.A., 1999. Maximizing questionnaire quality. In: Robinson, J.P., Shaver, P.R., Wrightsman, L.S. (Eds.), Measures of Political Attitudes. Academic Press, San Diego, 3757.

Krosnick, J.A., Narayan, S., Smith, W.R., 2004. Satisficing in surveys: Initial evidence. New Directions for Evaluation 70, 29-44.

Li, X., Low, A., Makhija, A.K., 2011. Career concerns and the busy life of the young CEO. Working paper, Ohio State University.

Loderer, C., Stulz, R.M., Waelchli, U., 2012. Why are old firms worth less? Working paper, University of Bern.

Loderer, C., Waelchli, U., 2010. Protecting minority shareholders: Listed versus unlisted firms. Financial Management 39, 33-57.

Loderer, C., Roth, L., Waelchli, U., Joerg, P., 2010. Shareholder value: Principles, declarations, and actions. Financial Management 39, 5-32.

Mace, M., 1986. Directors: Myth and Reality. Harvard University Press, Boston.

Medawar, P.B., 1952. An Unsolved Problem of Biology. H. K. Lewis, London. 
Morck, R., Shleifer, A., Vishny, R.W., 1988. Management ownership and market valuation: An empirical Analysis. Journal of Financial Economics 20, 293-315.

Morin, R.A., Fernandez Suarez, A., 1983. Risk aversion revisited. Journal of Finance 38, 12011216.

Ng, T.W.H., Feldman, D.C., 2008. The relationship of age to ten dimensions of job performance. Journal of Applied Psychology 93, 392-423.

Ong, A.D., Weiss, D.J., 2000. The impact of anonymity on responses to sensitive questions. Journal of Applied Psychology 30, 1691-1708.

Papke, L.E., Wooldridge, J.M., 1996. Econometric methods for fractional response variables with an application to 401(k) plan participation rates. Journal of Applied Econometrics 11, 619632.

Park, D.C., Reuter-Lorenz, P., 2009. The adaptive brain: Aging and neurocognitive scaffolding. Annual Review of Psychology 60, 173-196.

Parker, H., 1990. The company chairman-His role and responsibilities. Long Range Planning $23,35-43$.

Presser, S., Stinson, L., 1998. Data collection mode and social desirability bias in self-reported religious attendance. American Sociological Review 63, 137-145.

Rhodes, M.G., 2004. Age-related differences in performance on the Wisconsin card sorting test: A meta-analytic review. Psychology and Aging 19, 482-494.

Rose, N.L., Shepard, A., 1997. Firm diversification and CEO compensation: Managerial ability or executive entrenchment? RAND Journal of Economics 28, 489-514.

Salthouse, T.A., 2012. Consequences of age-related cognitive declines. Annual Review of Psychology 63, 201-226.

Taylor, R.N., 1975. Age and experience as determinants of managerial information processing and decision making performance. The Academy of Management Journal 18, 74-81.

Vafeas, N., 2003. Length of board tenure and outside director independence. Journal of Business Finance and Accounting 30, 1043-1064.

Verhaeghen, P., Salthouse, T.A., 1997. Meta-analyses of age-cognition relations in adulthood: Estimates of linear and nonlinear age effects and structural models. Psychological Bulletin $122,231-249$.

Waelchli, U., 2009. Corporate Governance von Schweizer Verwaltungsräten. Verlag im Internet $\mathrm{GmbH}$, Berlin. 
Weisberg, H.F., 2005. The Total Survey Error Approach: A guide to the New Science of Survey Research. University of Chicago Press, Chicago.

Yermack, D., 1996. Higher market valuation of companies with a small board of directors. Journal of Financial Economics 40, 185-211.

Yim, S., 2010. The acquisitiveness of youth: CEO age and acquisition behavior. Working paper, Emory University. 
Fig. 1. Non-parametric regressions.
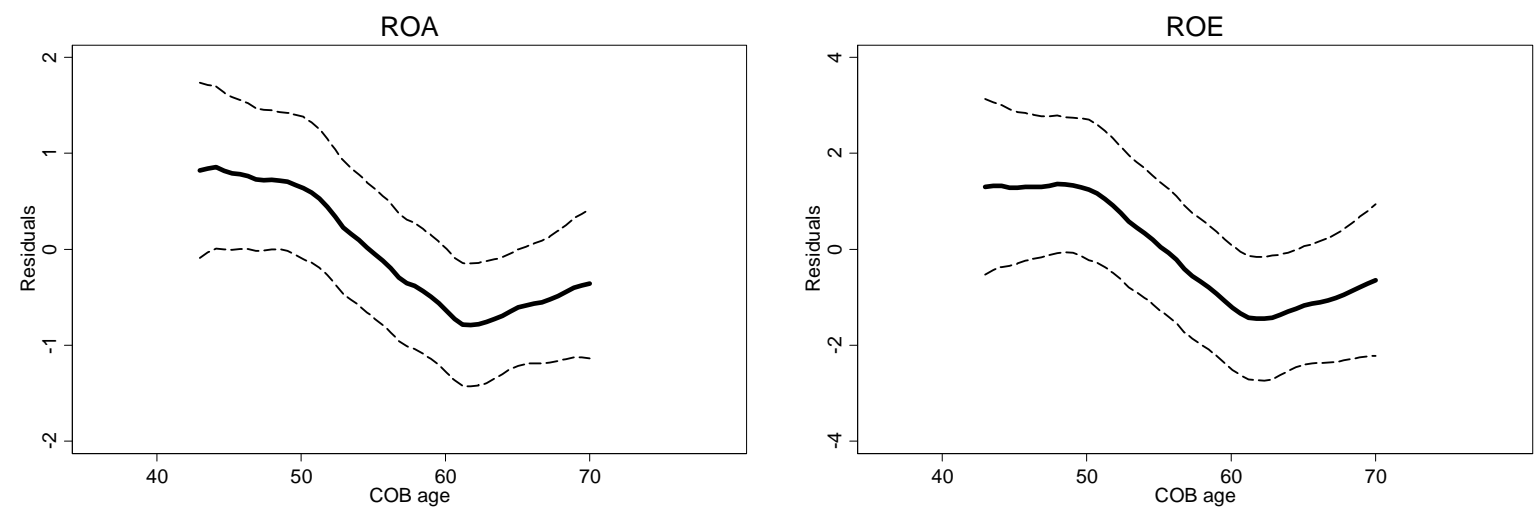

The Figure shows the results of kernel-weighted local polynomial regressions to investigate the functional form of the COB ageperformance relation. As the dependent variable, the graph uses residuals from OLS regressions of ROA (ROE) on the same control variables as in Table 4, except for COB age. The independent variable is COB age, winsorized at the bottom and top decile. The values are obtained using an Epanechnikov kernel function with a rule-of-thumb bandwidth estimator and local-mean smoothing. The dashed lines plot the 90-percent confidence band. 


\section{Table 1}

Variable definitions.

\begin{tabular}{|c|c|}
\hline Variable & Definition \\
\hline bAge limit & Binary variable equal to 1 if the firm has a mandatory retirement policy, and equal to 0 otherwise. \\
\hline bCEO-COB duality & $\begin{array}{l}\text { Binary variable equal to } 1 \text { if the same person is simultaneously CEO and COB, and equal to } 0 \\
\text { otherwise. }\end{array}$ \\
\hline bClosely held & $\begin{array}{l}\text { Binary variable equal to } 1 \text { if a single shareholder owns more than } 90 \text { percent of the voting rights, and } \\
\text { equal to } 0 \text { otherwise. }\end{array}$ \\
\hline bConfidential & $\begin{array}{l}\text { Binary variable equal to } 1 \text { if the respondent states that the questionnaire contains questions that touch } \\
\text { on potentially confidential issues, and equal to } 0 \text { otherwise. }\end{array}$ \\
\hline bMajority shareholder & $\begin{array}{l}\text { Binary variable equal to } 1 \text { if a single shareholder owns more than } 50 \text { percent of the voting rights, and } \\
\text { equal to } 0 \text { otherwise. }\end{array}$ \\
\hline bNot founder & Binary variable equal to 1 if the $\mathrm{COB}$ is not founder, and equal to 0 otherwise. \\
\hline bRisk perception & $\begin{array}{l}\text { Binary variable equal to } 1 \text { if the COB agreed to the statement 'The risks associated with a directorship } \\
\text { have increased in recent years', and equal to } 0 \text { otherwise. }\end{array}$ \\
\hline bTenure $<5$ & Binary variable equal to 1 if the COB's tenure is less than 5 years, and equal to 0 otherwise. \\
\hline bVariable compensation & $\begin{array}{l}\text { Binary variable equal to } 1 \text { if the } \mathrm{COB} \text { receives performance sensitive compensation, and equal to } 0 \\
\text { otherwise. }\end{array}$ \\
\hline Board independence & $\begin{array}{l}\text { Fraction of independent directors on the board. A director is classified as independent if he does not } \\
\text { have ties to the firm and did not have ties over the preceding three years. }\end{array}$ \\
\hline Board size & Number of directors on the board. \\
\hline COB age & Age of the COB (years). \\
\hline COB tenure & Term during which the COB held his position (years). \\
\hline Complexity & $\begin{array}{l}\text { The COB's assessment of the statement 'in recent years, it has become more difficult to be a director', } \\
\text { measured on a 5-point Likert scale. }\end{array}$ \\
\hline Family directors & Fraction of directors who are members of the founding family. \\
\hline Firm age & Number of years since the foundation of the company (years). \\
\hline Higher incentives & $\begin{array}{l}\text { The COB's assessment of the statement 'the COB prefers a more performance sensitive compensation } \\
\text { package', measured on an ordinal 5-point Likert scale. }\end{array}$ \\
\hline Leverage & The firm's leverage, calculated as the book value of debt divided by total assets. \\
\hline ROA & $\begin{array}{l}\text { The firm's return on assets, calculated as operating profit after taxes ( }=\text { net income }+ \text { interest expenses } \\
\text { after taxes) divided by book value of assets times } 100 \text {. We assume a cost of debt of } 4 \% \text {. }\end{array}$ \\
\hline ROE & The firm's return on equity, calculated as the net income divided by the book value of equity times 100 . \\
\hline ROEMP & $\begin{array}{l}\text { The firm's annual return per full-time equivalent employee, calculated as the net income divided by the } \\
\text { number of full-time equivalent employees (thousand CHF). }\end{array}$ \\
\hline NPM & $\begin{array}{l}\text { The firm's net profit margin, also known as return on sales, calculated as the net income divided by the } \\
\text { total annual sales times } 100 \text {. }\end{array}$ \\
\hline Sales to assets & The firm's ratio of annual sales to total assets. \\
\hline Shareholder value & $\begin{array}{l}\text { Based on the COB's assessment of the statement 'for our board, the firm's interests come prior to the } \\
\text { shareholders' interests'; measured on an ordinal 5-point Likert scale. To enhance readability, we } \\
\text { compute Shareholder value as } 6 \text { minus the COB's answer to the above statement. }\end{array}$ \\
\hline Size & The natural logarithm of the firm's total assets (million CHF). \\
\hline Survey time & The time that the COB took to fill in the questionnaire (minutes). \\
\hline vr Executives & Fraction of voting rights controlled by all executives. \\
\hline vr Founders & Fraction of voting rights controlled by the founders. \\
\hline vr Largest & Fraction of voting rights controlled by the largest blockholder. \\
\hline
\end{tabular}




\section{Table 2}

Descriptive statistics.

\begin{tabular}{|c|c|c|c|c|c|c|c|}
\hline & Mean & Std. & $\mathrm{p} 25$ & Med. & $\mathrm{p} 75$ & $\mathrm{~N}$ & IR $(\%)$ \\
\hline \multicolumn{8}{|l|}{ Firm characteristics } \\
\hline Assets (million CHF) & 28.34 & 46.92 & 4.27 & 10.00 & 25.00 & 1,101 & 72.72 \\
\hline Sales (million CHF) & 35.00 & 51.34 & 6.10 & 15.00 & 35.00 & 1,342 & 88.64 \\
\hline Net income (million CHF) & 1.36 & 2.45 & 0.10 & 0.39 & 1.20 & 1,133 & 74.83 \\
\hline Leverage & 0.43 & 0.27 & 0.19 & 0.44 & 0.66 & 1,022 & 67.50 \\
\hline Firm age (years) & 51.18 & 37.41 & 19.00 & 43.00 & 77.00 & 1,479 & 97.69 \\
\hline \multicolumn{8}{|l|}{ COB characteristics } \\
\hline COB age (years) & 56.81 & 9.62 & 49.00 & 57.00 & 64.00 & 1,502 & 99.21 \\
\hline COB tenure (years) & 15.51 & 10.30 & 7.00 & 14.00 & 22.00 & 1,488 & 98.28 \\
\hline \multicolumn{8}{|l|}{ Firm performance measures } \\
\hline ROA $(\%)$ & 7.67 & 6.89 & 2.96 & 5.13 & 10.47 & 963 & 63.61 \\
\hline ROE $(\%)$ & 11.98 & 13.43 & 2.64 & 7.20 & 16.67 & 950 & 62.75 \\
\hline NPM (\%) & 4.30 & 4.57 & 0.96 & 2.83 & 6.25 & 1,110 & 73.32 \\
\hline ROEMP (thousand CHF) & 14.39 & 19.89 & 1.82 & 6.07 & 16.90 & 1,110 & 73.32 \\
\hline Sales to assets & 1.85 & 1.26 & 0.92 & 1.54 & 2.50 & 1,081 & 71.40 \\
\hline \multicolumn{8}{|l|}{ Control Variables } \\
\hline bCEO-COB duality & 0.47 & - & - & - & - & 1,503 & 99.27 \\
\hline Board size & 3.90 & 1.48 & 3.00 & 4.00 & 5.00 & 1,500 & 99.08 \\
\hline Board independence & 0.24 & 0.30 & 0.00 & 0.00 & 0.40 & 1,487 & 98.22 \\
\hline Family directors & 0.38 & 0.37 & 0.00 & 0.33 & 0.67 & 1,487 & 98.22 \\
\hline vr Largest & 0.59 & 0.31 & 0.35 & 0.53 & 0.90 & 1,354 & 89.43 \\
\hline vr Founders & 0.46 & 0.45 & 0.00 & 0.42 & 1.00 & 1,176 & 77.68 \\
\hline vr Executives & 0.56 & 0.41 & 0.05 & 0.60 & 1.00 & 1,246 & 82.30 \\
\hline
\end{tabular}

All variables are winsorized at the $5^{\text {th }}$ and the $95^{\text {th }}$ percentile of their distribution (except for the binary variable $b C E O-C O B$ duality). 


\section{Table 3}

Pearson correlation coefficients.

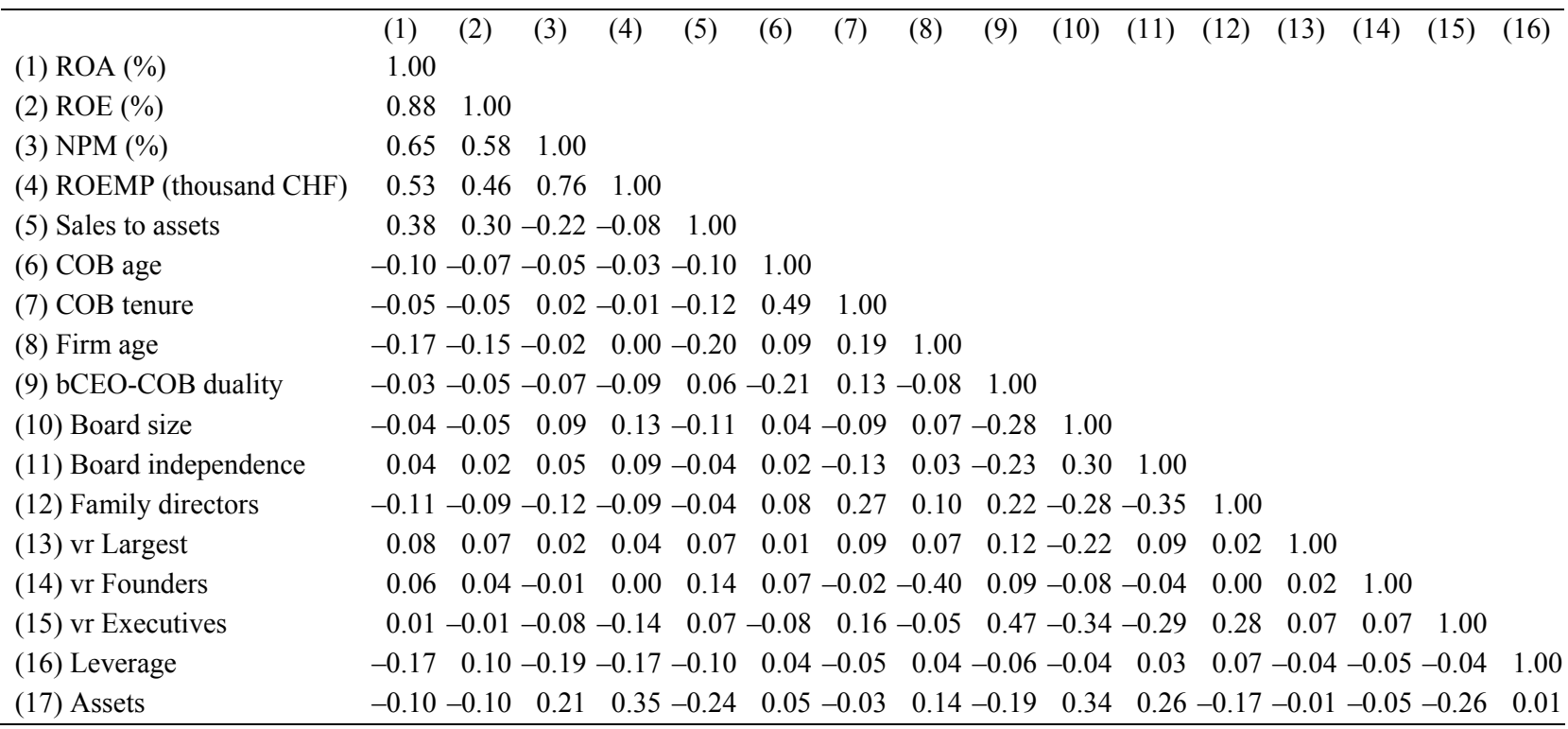


Table 4

COB age and firm performance.

\begin{tabular}{|c|c|c|c|c|c|}
\hline & $\begin{array}{l}\text { ROA } \\
\text { (1) }\end{array}$ & $\begin{array}{l}\text { ROE } \\
(2)\end{array}$ & $\begin{array}{l}\text { NPM } \\
(3)\end{array}$ & $\begin{array}{l}\text { ROEMP } \\
\text { (4) }\end{array}$ & $\begin{array}{l}\text { Sales to assets } \\
\text { (5) }\end{array}$ \\
\hline COB age & $\begin{array}{l}-0.082 * * \\
(0.033 ;-10.3)\end{array}$ & $\begin{array}{l}-0.144 * * \\
(0.067 ;-11.5)\end{array}$ & $\begin{array}{l}-0.042 * * \\
(0.020 ;-9.4)\end{array}$ & $\begin{array}{l}-0.151^{*} \\
(0.085 ;-10.1)\end{array}$ & $\begin{array}{l}-0.004 \\
(0.006)\end{array}$ \\
\hline COB tenure & $\begin{array}{c}0.039 \\
(0.033)\end{array}$ & $\begin{array}{c}0.072 \\
(0.067)\end{array}$ & $\begin{array}{c}0.033 \\
(0.020)\end{array}$ & $\begin{array}{c}0.083 \\
(0.087)\end{array}$ & $\begin{array}{l}-0.006 \\
(0.006)\end{array}$ \\
\hline $\ln$ (firm age) & $\begin{array}{l}-0.779 * * \\
(0.324 ;-5.6)\end{array}$ & $\begin{array}{l}-1.538 * * \\
(0.669 ;-7.0)\end{array}$ & $\begin{array}{l}-0.111 \\
(0.233)\end{array}$ & $\begin{array}{c}-1.366 \\
(0.863)\end{array}$ & $\begin{array}{l}-0.168^{* * * *} \\
(0.061 ;-5.0)\end{array}$ \\
\hline bCEO-COB duality & $\begin{array}{l}-1.268 * * \\
(0.608 ;-16.5)\end{array}$ & $\begin{array}{l}-2.662 * * \\
(1.192 ;-22.2)\end{array}$ & $\begin{array}{l}-0.495 \\
(0.384)\end{array}$ & $\begin{array}{c}-1.329 \\
(1.531)\end{array}$ & $\begin{array}{l}-0.043 \\
(0.107)\end{array}$ \\
\hline Board size & $\begin{array}{l}-0.078 \\
(0.212)\end{array}$ & $\begin{array}{l}-0.254 \\
(0.433)\end{array}$ & $\begin{array}{c}0.002 \\
(0.146)\end{array}$ & $\begin{array}{c}-0.452 \\
(0.596)\end{array}$ & $\begin{array}{l}-0.000 \\
(0.035)\end{array}$ \\
\hline Board independence & $\begin{array}{c}0.453 \\
(1.012)\end{array}$ & $\begin{array}{l}-1.162 \\
(1.972)\end{array}$ & $\begin{array}{l}-0.240 \\
(0.646)\end{array}$ & $\begin{array}{l}-0.564 \\
(2.681)\end{array}$ & $\begin{array}{c}0.076 \\
(0.180)\end{array}$ \\
\hline Family directors & $\begin{array}{l}-1.703 * * \\
(0.843 ;-8.2)\end{array}$ & $\begin{array}{l}-3.790 * * \\
(1.654 ;-11.7)\end{array}$ & $\begin{array}{l}-0.860 * \\
(0.516 ;-7.4)\end{array}$ & $\begin{array}{c}-0.948 \\
(2.038)\end{array}$ & $\begin{array}{l}-0.136 \\
(0.135)\end{array}$ \\
\hline vr Largest & $\begin{array}{l}2.105^{* *} \\
(0.919 ; 8.5)\end{array}$ & $\begin{array}{l}4.539 * * \\
(1.908 ; 11.7)\end{array}$ & $\begin{array}{c}0.516 \\
(0.567)\end{array}$ & $\begin{array}{c}1.936 \\
(2.276)\end{array}$ & $\begin{array}{l}0.331 * * \\
(0.160 ; 5.5)\end{array}$ \\
\hline vr Founders & $\begin{array}{c}0.144 \\
(0.627)\end{array}$ & $\begin{array}{c}0.073 \\
(1.294)\end{array}$ & $\begin{array}{c}0.183 \\
(0.425)\end{array}$ & $\begin{array}{c}0.543 \\
(1.585)\end{array}$ & $\begin{array}{c}0.069 \\
(0.107)\end{array}$ \\
\hline vr Executives & $\begin{array}{l}-0.040 \\
(0.742)\end{array}$ & $\begin{array}{l}-0.686 \\
(1.528)\end{array}$ & $\begin{array}{l}-0.086 \\
(0.506)\end{array}$ & $\begin{array}{l}-1.232 \\
(1.907)\end{array}$ & $\begin{array}{l}-0.050 \\
(0.138)\end{array}$ \\
\hline Leverage & $\begin{array}{l}-3.568 * * * \\
(1.022 ;-12.6)\end{array}$ & $\begin{array}{c}6.127 * * * \\
(2.118 ; 13.8)\end{array}$ & $\begin{array}{l}-2.707 * * * \\
(0.603 ;-17.0)\end{array}$ & $\begin{array}{l}-12.277 * * * \\
\quad(2.392 ;-23.0)\end{array}$ & $\begin{array}{l}-0.361^{* *} \\
(0.163 ;-5.3)\end{array}$ \\
\hline Size & $\begin{array}{l}-0.831 * * * \\
(0.240 ;-5.6)\end{array}$ & $\begin{array}{l}-1.340 * * * \\
(0.465 ;-5.8)\end{array}$ & $\begin{array}{c}0.622 * * * \\
(0.172 ; 7.5)\end{array}$ & $\begin{array}{l}5.583 * * * \\
(0.716 ; 20.1)\end{array}$ & $\begin{array}{l}-0.330^{* * * *} \\
(0.046 ;-9.2)\end{array}$ \\
\hline Constant & $\begin{array}{l}17.256^{* * *} \\
(2.991)\end{array}$ & $\begin{array}{l}23.056^{* * *} \\
(5.690)\end{array}$ & $\begin{array}{l}8.015^{* * *} \\
(2.472)\end{array}$ & $\begin{array}{l}31.070 * * * \\
(10.396)\end{array}$ & $\begin{array}{l}3.245^{* * *} \\
(0.524)\end{array}$ \\
\hline Industry fixed effects & Included & Included & Included & Included & Included \\
\hline Observations & 694 & 685 & 684 & 683 & 722 \\
\hline Adjusted R-squared & 0.084 & 0.058 & 0.141 & 0.227 & 0.162 \\
\hline
\end{tabular}

The table investigates the relation between COB age and firm performance. In regression (1), the dependent variable is $R O A$. In regressions (2), (3), (4), and (5), the dependent variable is ROE, NPM, ROEMP, and Sales to assets, respectively. All regressions are estimated with OLS. The first argument in parentheses shows robust standard errors. For significant coefficients, we add a second argument that shows the sensitivity of the dependent variable (in \%) to an increase in the independent variable of one standard deviation. In the case of $b C E O-C O B$ duality, the sensitivity is for a change from 0 to 1 .

* Significance at the $10 \%$ level for two-tailed tests.

** Significance at the $5 \%$ level for two-tailed tests.

*** Significance at the $1 \%$ level for two-tailed tests. 
Table 5

Piecewise $\mathrm{COB}$ age and firm performance.

\begin{tabular}{|c|c|c|c|c|c|}
\hline & $\begin{array}{l}\text { ROA } \\
\text { (1) }\end{array}$ & $\begin{array}{l}\text { ROE } \\
(2)\end{array}$ & $\begin{array}{l}\text { NPM } \\
\text { (3) }\end{array}$ & $\begin{array}{l}\text { ROEMP } \\
\text { (4) }\end{array}$ & $\begin{array}{l}\text { Sales to assets } \\
\text { (5) }\end{array}$ \\
\hline COB age $<50$ & $\begin{array}{l}-0.063 \\
(0.135)\end{array}$ & $\begin{array}{l}-0.063 \\
(0.271)\end{array}$ & $\begin{array}{l}-0.007 \\
(0.081)\end{array}$ & $\begin{array}{c}0.230 \\
(0.282)\end{array}$ & $\begin{array}{c}0.005 \\
(0.022)\end{array}$ \\
\hline $50 \leq \mathrm{COB}$ age $<65$ & $\begin{array}{l}-0.127 * * \\
(0.064 ;-14.9)\end{array}$ & $\begin{array}{l}-0.248 * * \\
(0.126 ;-18.2)\end{array}$ & $\begin{array}{l}-0.119 * * * \\
(0.039 ;-26.3)\end{array}$ & $\begin{array}{l}-0.471 * * * \\
(0.156 ;-31.1)\end{array}$ & $\begin{array}{c}-0.003 \\
(0.010)\end{array}$ \\
\hline $65 \leq \mathrm{COB}$ age & $\begin{array}{c}0.051 \\
(0.104)\end{array}$ & $\begin{array}{c}0.123 \\
(0.212)\end{array}$ & $\begin{array}{l}0.178^{* * *} \\
(0.068)\end{array}$ & $\begin{array}{l}0.542 * * \\
(0.246)\end{array}$ & $\begin{array}{l}-0.020 \\
(0.022)\end{array}$ \\
\hline $\mathrm{COB}$ tenure & $\begin{array}{c}0.035 \\
(0.033)\end{array}$ & $\begin{array}{c}0.064 \\
(0.067)\end{array}$ & $\begin{array}{c}0.028 \\
(0.020)\end{array}$ & $\begin{array}{c}0.059 \\
(0.087)\end{array}$ & $\begin{array}{l}-0.006 \\
(0.006)\end{array}$ \\
\hline $\ln$ (firm age) & $\begin{array}{l}-0.774 * * \\
(0.325 ;-5.5)\end{array}$ & $\begin{array}{l}-1.526^{* *} \\
(0.675 ;-7.0)\end{array}$ & $\begin{array}{l}-0.107 \\
(0.232)\end{array}$ & $\begin{array}{l}-1.287 \\
(0.857)\end{array}$ & $\begin{array}{l}-0.164 * * * \\
(0.062 ;-4.9)\end{array}$ \\
\hline bCEO-COB duality & $\begin{array}{l}-1.199 * \\
(0.613 ;-15.6)\end{array}$ & $\begin{array}{l}-2.536^{* *} \\
(1.205 ;-21.2)\end{array}$ & $\begin{array}{l}-0.380 \\
(0.382)\end{array}$ & $\begin{array}{l}-0.964 \\
(1.527)\end{array}$ & $\begin{array}{l}-0.055 \\
(0.109)\end{array}$ \\
\hline Board size & $\begin{array}{l}-0.068 \\
(0.212)\end{array}$ & $\begin{array}{l}-0.232 \\
(0.430)\end{array}$ & $\begin{array}{c}0.020 \\
(0.145)\end{array}$ & $\begin{array}{l}-0.366 \\
(0.591)\end{array}$ & $\begin{array}{c}0.000 \\
(0.036)\end{array}$ \\
\hline Board independence & $\begin{array}{c}0.498 \\
(1.012)\end{array}$ & $\begin{array}{l}-1.036 \\
(1.977)\end{array}$ & $\begin{array}{l}-0.183 \\
(0.649)\end{array}$ & $\begin{array}{l}-0.203 \\
(2.679)\end{array}$ & $\begin{array}{c}0.077 \\
(0.180)\end{array}$ \\
\hline Family directors & $\begin{array}{l}-1.728 * * \\
(0.849 ;-8.3)\end{array}$ & $\begin{array}{l}-3.796 * * \\
(1.664 ;-11.7)\end{array}$ & $\begin{array}{l}-0.910^{*} \\
(0.514 ;-7.8)\end{array}$ & $\begin{array}{l}-0.767 \\
(2.014)\end{array}$ & $\begin{array}{l}-0.120 \\
(0.137)\end{array}$ \\
\hline vr Largest & $\begin{array}{c}2.055^{* *} \\
(0.926 ; 8.3)\end{array}$ & $\begin{array}{l}4.458 * * \\
(1.923 ; 11.5)\end{array}$ & $\begin{array}{c}0.437 \\
(0.566)\end{array}$ & $\begin{array}{c}1.774 \\
(2.288)\end{array}$ & $\begin{array}{l}0.340 * * \\
(0.161 ; 5.7)\end{array}$ \\
\hline vr Founders & $\begin{array}{c}0.109 \\
(0.626)\end{array}$ & $\begin{array}{c}0.003 \\
(1.287)\end{array}$ & $\begin{array}{c}0.115 \\
(0.419)\end{array}$ & $\begin{array}{c}0.401 \\
(1.561)\end{array}$ & $\begin{array}{c}0.077 \\
(0.109)\end{array}$ \\
\hline vr Executives & $\begin{array}{l}-0.084 \\
(0.745)\end{array}$ & $\begin{array}{l}-0.760 \\
(1.538)\end{array}$ & $\begin{array}{l}-0.155 \\
(0.507)\end{array}$ & $\begin{array}{l}-1.434 \\
(1.894)\end{array}$ & $\begin{array}{l}-0.044 \\
(0.139)\end{array}$ \\
\hline Leverage & $\begin{array}{l}-3.599 * * * \\
(1.024 ;-12.7)\end{array}$ & $\begin{array}{c}6.089 * * * \\
(2.125 ; 13.7)\end{array}$ & $\begin{array}{l}-2.775 * * * \\
(0.604 ;-17.4)\end{array}$ & $\begin{array}{l}-12.267 * * * \\
(2.386 ;-23.0)\end{array}$ & $\begin{array}{l}-0.354 * * \\
(0.163 ;-5.2)\end{array}$ \\
\hline Size & $\begin{array}{l}-0.825 * * * \\
(0.240 ;-5.6)\end{array}$ & $\begin{array}{l}-1.341 * * * \\
(0.464 ;-5.8)\end{array}$ & $\begin{array}{c}0.632 * * * \\
(0.171 ; 7.6)\end{array}$ & $\begin{array}{l}5.575 * * * \\
(0.707 ; 20.1)\end{array}$ & $\begin{array}{l}-0.333 * * * \\
(0.046 ;-9.3)\end{array}$ \\
\hline Constant & $\begin{array}{l}16.491^{* *} \\
(6.830)\end{array}$ & $\begin{array}{l}19.651 \\
(13.559)\end{array}$ & $\begin{array}{c}6.541 \\
(4.313)\end{array}$ & $\begin{array}{l}13.831 \\
(15.317)\end{array}$ & $\begin{array}{l}2.769 * * \\
(1.183)\end{array}$ \\
\hline Industry fixed effects & Included & Included & Included & Included & Included \\
\hline Observations & 694 & 685 & 684 & 683 & 722 \\
\hline Adjusted R-squared & 0.083 & 0.057 & 0.150 & 0.233 & 0.161 \\
\hline
\end{tabular}

The table investigates the functional form of the relation between COB age and firm performance by estimating piecewise linear regressions. The dependent variables are the same as in Table 4. All regressions are estimated with OLS. The first argument in parentheses shows robust standard errors. For significant control variables, we add a second argument that shows the sensitivity of the dependent variable (in \%) to an increase in the independent variable of one standard deviation. For the piecewise COB age measure, we investigate the impact of plus/minus half a standard deviation (4.8 years) around mean COB age (56.8 years). Therefore, the two cases we project are $\mathrm{COB}$ age 52 years $(C O B$ age $<50=49 ; 50 \leq C O B$ age $<65=3)$ and COB age 61.6 years $(C O B$ age $<50=49 ; 50 \leq C O B$ age $<65=12.6)$. In the case of $b C E O-C O B$ duality, the sensitivity is for a change from 0 to 1 .

* Significance at the $10 \%$ level for two-tailed tests.

** Significance at the $5 \%$ level for two-tailed tests.

*** Significance at the $1 \%$ level for two-tailed tests. 


\section{Table 6}

Owner-managed firms and the old guard.

\begin{tabular}{|c|c|c|c|c|}
\hline & \multicolumn{4}{|c|}{ Dependent variable: ROA } \\
\hline & (1) & (2) & (3) & (4) \\
\hline COB age & $\begin{array}{l}-0.105 * * * \\
(0.037 ;-13.1)\end{array}$ & $\begin{array}{l}-0.156 * * * \\
(0.052 ;-19.5)\end{array}$ & $\begin{array}{l}-0.139 * * \\
(0.063 ;-17.4)\end{array}$ & $\begin{array}{l}-0.082 * * \\
(0.035 ;-10.3)\end{array}$ \\
\hline bClosely held & $\begin{array}{l}-0.131 \\
(0.976)\end{array}$ & & & \\
\hline COB age $\times$ bClosely held & $\begin{array}{c}0.087 \\
(0.061)\end{array}$ & & & \\
\hline bMajority shareholder & & $\begin{array}{l}-0.210 \\
(0.853)\end{array}$ & & \\
\hline COB age $\times$ bMajority shareholder & & $\begin{array}{l}0.110^{*} \\
(0.058 ; 13.8)\end{array}$ & & \\
\hline bNot founder & & & $\begin{array}{c}0.039 \\
(0.815)\end{array}$ & \\
\hline $\mathrm{COB}$ age $\times$ bNot founder & & & $\begin{array}{c}0.072 \\
(0.069)\end{array}$ & \\
\hline bTenure $<5$ & & & & $\begin{array}{c}0.625 \\
(0.965)\end{array}$ \\
\hline COB age $\times$ bTenure $<5$ & & & & $\begin{array}{c}-0.001 \\
(0.094)\end{array}$ \\
\hline $\mathrm{COB}$ tenure & $\begin{array}{c}0.039 \\
(0.033)\end{array}$ & $\begin{array}{c}0.041 \\
(0.033)\end{array}$ & $\begin{array}{c}0.038 \\
(0.034)\end{array}$ & $\begin{array}{c}0.050 \\
(0.035)\end{array}$ \\
\hline Other controls & Included & Included & Included & Included \\
\hline Industry fixed effects & Included & Included & Included & Included \\
\hline Observations & 694 & 694 & 694 & 694 \\
\hline Adjusted R-squared & 0.075 & 0.077 & 0.074 & 0.073 \\
\hline
\end{tabular}

We interact COB age (demeaned) with the following dummy variables: 1) bClosely held; 2) bMajority shareholder; 3) bNot founder; and 4) bTenure $<5$. All regressions are estimated with OLS. The dependent variable is $R O A$. To preserve space, we do not report the coefficients of the control variables. The first argument in parentheses shows robust standard errors. For significant control variables, we add a second argument that shows the sensitivity of the dependent variable (in \%) to an increase in the independent variable of one standard deviation. For the interaction term, we keep bMajority shareholder at 1 and vary COB age.

* Significance at the $10 \%$ level for two-tailed tests.

** Significance at the $5 \%$ level for two-tailed tests.

*** Significance at the $1 \%$ level for two-tailed tests. 


\section{Table 7}

Sample selection.

\begin{tabular}{lcc}
\hline & Dependent variable: ROA & Dependent variable: ROE \\
\hline First step: $b$ Confidential & $-0.870^{* * *}$ & $-0.859^{* * *}$ \\
& $(0.090)$ & $(0.090)$ \\
Controls (selection) & Included & Included \\
& & \\
Second step: $C O B$ age & $-0.077^{* *}$ & $-0.132^{* * *}$ \\
& $(0.034 ;-9.6)$ & $(0.067 ;-10.6)$ \\
Controls & Included & Included \\
Inverese mills ratio & 1.306 & 3.898 \\
& $(1.279)$ & $(2.607)$ \\
\hline
\end{tabular}

We estimate Heckman (1979) selection models with $R O A$ and $R O E$ as dependent variables. The selection variable is bConfidential, a dummy variable that identifies respondents who state that the questionnaire contains questions that touch on potentially confidential issues.

* Significance at the $10 \%$ level for two-tailed tests.

** Significance at the $5 \%$ level for two-tailed tests.

*** Significance at the $1 \%$ level for two-tailed tests. 


\section{Table 8a}

Descriptive statistics for cognitive abilities.

\begin{tabular}{lclcl}
\hline & Mean & Sd. & Median & $\mathrm{N}$ \\
\hline Survey time & 21.56 & 9.34 & 20.00 & 1,347 \\
Complexity & 4.11 & 1.20 & 5.00 & 1,449 \\
\hline
\end{tabular}




\section{Table 8b}

COB age and cognitive abilities.

\begin{tabular}{llccc}
\hline & \multicolumn{2}{l}{ Dependent variable: Survey time } & \multicolumn{2}{l}{ Dependent variable: Complexity } \\
\cline { 2 - 4 } & $(1)$ & $(2)$ & $(3)$ & $(4)$ \\
\hline COB age & $0.243^{* * *}$ & & $0.020^{* *}$ & \\
& $(0.047 ; 10.8)$ & $0.009 ; 4.2)$ & 0.009 \\
COB age $<50$ & & & $(0.034)$ \\
& & 0.147 & $0.046^{* *}$ \\
$50 \leq$ COB age $<65$ & & $(0.149)$ & & $(0.018 ; 8.0)$ \\
& & $0.269 * * *$ & -0.051 \\
$65 \leq$ COB age & $(0.088 ; 9.7)$ & & $(0.033)$ \\
& & 0.261 & $-0.017^{*}$ \\
COB tenure & 0.023 & $(0.186)$ & $(0.009 ;-3.8)$ & $(0.009 ;-3.5)$ \\
Other controls & $(0.045)$ & $(0.024$ & Included & Included \\
Industry fixed effects & Included & Included & Included & Included \\
Observations & & Included & & 719 \\
Adjusted R-squared & 697 & 697 & 719 & 0.036 \\
Wald chi-2 & 0.084 & 0.082 & 0.033 & $67.567^{* * *}$ \\
\hline
\end{tabular}

The table asks whether the COBs' cognitive abilities change with age. The proxies for cognitive abilities are Survey time and Complexity, respectively. We show the results from multivariate OLS regressions (1 and 2$)$ and ordered logit regressions ( 3 and 4). In regressions (1) and (2), the dependent variable is Survey time. Regressions (3) and (4) investigate the determining factors of Complexity. In addition to the linear $\mathrm{COB}$ age measure (regressions 1 and 3), we also estimate piecewise linear models (regressions 2 and 4). The first argument in parentheses shows robust standard errors. For significant control variables, we add a second argument that shows the sensitivity of the dependent variable (in \%) to an increase in the independent variable of one standard deviation. For the piecewise COB age measure, we investigate the impact of plus/minus half a standard deviation (4.8 years) around mean $\mathrm{COB}$ age (56.8 years). Therefore, the two cases we project are COB age 52 years (COB age $<50=49 ; 50 \leq$ $C O B$ age $<65=3)$ and $\mathrm{COB}$ age 61.6 years $(C O B$ age $<50=49 ; 50 \leq C O B$ age $<65=12.6)$. To assess the marginal effects in the ordered logit regressions (3) and (4), we compute the change in the cumulative predicted probabilities of the two categories 'I strongly agree' and 'I agree.'

* Significance at the $10 \%$ level for two-tailed tests.

** Significance at the 5\% level for two-tailed tests.

*** Significance at the $1 \%$ level for two-tailed tests. 


\section{Table 9a}

Descriptive statistics for business objectives and compensation.

\begin{tabular}{lllll}
\hline & Mean & Sd. & Median & $\mathrm{N}$ \\
\hline Shareholder value & 1.82 & 1.17 & 1.00 & 1,443 \\
bVariable compensation & 0.19 & - & - & 1,144 \\
Higher incentives & 2.18 & 1.38 & 2.00 & 1,434 \\
bRisk perception & 0.81 & - & - & 1,448 \\
\hline
\end{tabular}

Our proxy for business objectives is Shareholder value. To assess the COBs' financial incentives, we use the actual structure of the compensation package (bVariable compensation) as well as the desired structure (Higher incentives). 


\section{Table 9b}

Multivariate regressions for business objectives and compensation.

\begin{tabular}{|c|c|c|c|c|}
\hline & $\begin{array}{l}\text { Shareholder value } \\
\text { (1) }\end{array}$ & $\begin{array}{l}\text { bVariable compensation } \\
\text { (2) }\end{array}$ & $\begin{array}{l}\text { Higher incentives } \\
\text { (3) }\end{array}$ & (4) \\
\hline $\mathrm{COB}$ age & $\begin{array}{l}-0.024 * * \\
(0.010 ;-17.2)\end{array}$ & $\begin{array}{l}-0.032 * * \\
(0.014 ;-20.6)\end{array}$ & $\begin{array}{l}-0.023 * * \\
(0.010 ;-15.0)\end{array}$ & $\begin{array}{l}-0.022 * * \\
(0.010 ;-14.7\end{array}$ \\
\hline COB tenure & $\begin{array}{l}-0.009 \\
(0.010)\end{array}$ & $\begin{array}{l}0.031 * * \\
(0.014 ; 26.5)\end{array}$ & $\begin{array}{l}-0.004 \\
(0.009)\end{array}$ & $\begin{array}{c}-0.004 \\
(0.009)\end{array}$ \\
\hline bRisk perception & & & & $\begin{array}{l}0.300 * \\
(0.181 ; 25.5)\end{array}$ \\
\hline Other controls & Included & Included & Included & Included \\
\hline Industry fixed effects & Included & Included & Included & Included \\
\hline Observations & 718 & 595 & 715 & 713 \\
\hline Adjusted R-squared & 0.040 & 0.063 & 0.019 & 0.020 \\
\hline Wald chi-2 & $61.180^{* * *}$ & $35.088 * * *$ & $792.579 * * *$ & $853.604 * * *$ \\
\hline
\end{tabular}

The table shows the results from multivariate regressions of business objectives and compensation on COB age and controls. Regressions (1), (3), and (4) are estimated with an ordered logit model. Regression (2) uses a logit model. For significant variables, we add a second argument that shows the sensitivity of the dependent variable (in \%) to an increase in the independent variable by one standard deviation. In the case of bRisk perception, the sensitivity is for a change from 0 to 1 . To assess the marginal effects in the ordered logit regressions (1), (3), and (4), we compute the change in the cumulative predicted probabilities of the two categories 'I strongly agree' and 'I agree.' For the logit regression, we compute the change in the probability of a positive outcome.

* Significance at the $10 \%$ level for two-tailed tests.

** Significance at the $5 \%$ level for two-tailed tests.

$* * * \quad$ Significance at the $1 \%$ level for two-tailed tests. 


\section{Table 9c}

Descriptive statistics for job activities.

\begin{tabular}{lccccccccccc}
\hline & \multicolumn{3}{l}{ Actual time allocation } & \multicolumn{4}{c}{ Target time allocation } & \multicolumn{2}{c}{ Mean } \\
& \cline { 2 - 10 } & Mean & Sd. & Median & $\mathrm{N}$ & Mean & Sd. & Median & $\mathrm{N}$ & comparison \\
\hline Strategic tasks & 0.272 & 0.186 & 0.20 & 1,255 & 0.312 & 0.172 & 30.00 & 831 & $* * *$ & $*$ \\
Monitoring activities & 0.278 & 0.158 & 0.26 & 1,251 & 0.262 & 0.139 & 25.00 & 831 & $* *$ \\
Controlling, reporting, and auditing & 0.280 & 0.172 & 0.25 & 1,255 & 0.253 & 0.147 & 25.00 & 832 & $* * *$ & - \\
Interaction with external stakeholders & 0.145 & 0.168 & 0.10 & 1,253 & 0.151 & 0.155 & 10.00 & 831 & - \\
Other activities & 0.036 & 0.103 & 0.00 & 1,228 & 0.028 & 0.081 & 0.00 & 808 & $* *$ \\
\hline
\end{tabular}

The table shows how much time the COBs dedicate to 1) strategic tasks, 2) monitoring activities, 3) controlling, reporting, and auditing, 4) interaction with external stakeholders, and 5) other activities. We measure both the actual and the target time allocation to these functions.

** Significance at the $5 \%$ level for two-tailed tests.

*** Significance at the $1 \%$ level for two-tailed tests. 


\section{Table 9d}

Multivariate regressions for job activities.

\begin{tabular}{|c|c|c|c|c|c|c|}
\hline & \multicolumn{3}{|c|}{ Actual time allocation } & \multicolumn{3}{|c|}{ Target time allocation } \\
\hline & COB age & COB tenure & Controls, IFE & COB age & COB tenure & Controls, IFE \\
\hline Strategic tasks & $\begin{array}{c}-0.003 \\
(0.005)\end{array}$ & $\begin{array}{c}-0.003 \\
(0.004)\end{array}$ & Included & $\begin{array}{c}-0.007 \\
(0.005)\end{array}$ & $\begin{array}{l}-0.005 \\
(0.004)\end{array}$ & Included \\
\hline Monitoring activities & $\begin{array}{c}0.000 \\
(0.004)\end{array}$ & $\begin{array}{l}-0.007 * \\
(0.004 ;-4.8)\end{array}$ & Included & $\begin{array}{c}0.000 \\
(0.005)\end{array}$ & $\begin{array}{l}-0.003 \\
(0.004)\end{array}$ & Included \\
\hline Controlling, reporting, and auditing & $\begin{array}{c}0.012 * * * \\
(0.004 ; 8.5)\end{array}$ & $\begin{array}{c}0.002 \\
(0.004)\end{array}$ & Included & $\begin{array}{c}0.011 * * \\
(0.005 ; 8.2)\end{array}$ & $\begin{array}{c}0.002 \\
(0.005)\end{array}$ & Included \\
\hline Interaction with external stakeholders & $\begin{array}{l}-0.010 * \\
(0.006 ;-8.0)\end{array}$ & $\begin{array}{c}0.009 \\
(0.006)\end{array}$ & Included & $\begin{array}{l}-0.005 \\
(0.006)\end{array}$ & $\begin{array}{c}0.009 \\
(0.007)\end{array}$ & Included \\
\hline Other activities & $\begin{array}{l}0.027 * * \\
(0.013 ; 27.6)\end{array}$ & $\begin{array}{l}-0.007 \\
(0.014)\end{array}$ & Included & $\begin{array}{c}0.053 * * * \\
(0.017 ; 61.9)\end{array}$ & $\begin{array}{l}-0.020 \\
(0.017)\end{array}$ & Included \\
\hline
\end{tabular}

The table studies the relation between $\mathrm{COB}$ age and job activities in a multivariate framework. Each row shows the results of two separate regressions of the job activity listed to the left of the table on $C O B$ age, $C O B$ tenure, and the standard controls (including industry fixed effects, IFE). To preserve space, we only report the coefficients of $C O B$ age and $C O B$ tenure. The left (right) part of the table refers to the COBs' actual (target) time allocation. The first argument in parentheses shows robust standard errors. For significant variables, we add a second argument that shows the sensitivity of the dependent variable (in \%) to an increase in the independent variable by one standard deviation.

* Significance at the $10 \%$ level for two-tailed tests.

** Significance at the $5 \%$ level for two-tailed tests.

*** Significance at the $1 \%$ level for two-tailed tests. 


\section{Table 10}

COB age, determinants of job performance, and firm performance.

\begin{tabular}{|c|c|c|c|c|c|c|}
\hline & \multicolumn{6}{|c|}{ Dependent variable: ROA } \\
\hline & (1) & (2) & (3) & (4) & (5) & $(6)$ \\
\hline COB age & $\begin{array}{l}-0.082 * * \\
(0.033 ;-10.3)\end{array}$ & $\begin{array}{l}-0.063 * \\
(0.034 ;-7.9)\end{array}$ & $\begin{array}{l}-0.071 * * \\
(0.033 ;-8.9)\end{array}$ & $\begin{array}{l}-0.074 * * \\
(0.036 ;-9.3)\end{array}$ & $\begin{array}{l}-0.074 * * \\
(0.033 ;-9.3)\end{array}$ & $\begin{array}{c}-0.043 \\
(0.038)\end{array}$ \\
\hline \multicolumn{7}{|l|}{ Cognitive abilities } \\
\hline Survey time & & $\begin{array}{l}-0.093 * * * \\
(0.027 ;-11.3)\end{array}$ & & & & $\begin{array}{l}-0.104 * * * \\
(0.030 ;-12.7)\end{array}$ \\
\hline \multicolumn{7}{|l|}{ Motivation } \\
\hline Shareholder value & & & $\begin{array}{l}0.463 * \\
(0.251 ; 11.0)\end{array}$ & & & $\begin{array}{l}0.444 * \\
(0.268 ; 10.5)\end{array}$ \\
\hline Strategic tasks (actual) & & & & $\begin{array}{c}1.912 \\
(1.560)\end{array}$ & & $\begin{array}{c}1.695 \\
(1.710)\end{array}$ \\
\hline Controlling, rep., aud. (actual) & & & & $\begin{array}{l}-0.221 \\
(1.675)\end{array}$ & & $\begin{array}{c}0.607 \\
(1.761)\end{array}$ \\
\hline Higher incentives & & & & & $\begin{array}{c}0.139 \\
(0.194)\end{array}$ & $\begin{array}{c}0.041 \\
(0.211)\end{array}$ \\
\hline $\mathrm{COB}$ tenure & $\begin{array}{c}0.039 \\
(0.033)\end{array}$ & $\begin{array}{c}0.040 \\
(0.034)\end{array}$ & $\begin{array}{c}0.037 \\
(0.033)\end{array}$ & $\begin{array}{c}0.041 \\
(0.036)\end{array}$ & $\begin{array}{c}0.035 \\
(0.033)\end{array}$ & $\begin{array}{c}0.038 \\
(0.039)\end{array}$ \\
\hline Other controls & Included & Included & Included & Included & Included & Included \\
\hline Industry fixed effects & Included & Included & Included & Included & Included & Included \\
\hline Observations & 694 & 661 & 681 & 619 & 678 & 583 \\
\hline Adjusted R-squared & 0.084 & 0.099 & 0.085 & 0.081 & 0.081 & 0.102 \\
\hline
\end{tabular}

The table asks whether changes in cognitive abilities and motivation can explain the COB age effect we observe. The dependent variable is $R O A$. All regressions are estimated with OLS. To preserve space, we only report the coefficients of $C O B$ age, $C O B$ tenure, and the proxies for abilities and motivation. The first argument in parentheses shows robust standard errors. For significant variables, we add a second argument that shows the sensitivity of the dependent variable (in \%) to an increase in the independent variable of one standard deviation. In the case of Shareholder value, the sensitivity is for a change from 'neutral' to 'strongly agree.'

* Significance at the $10 \%$ level for two-tailed tests.

** Significance at the $5 \%$ level for two-tailed tests.

*** Significance at the $1 \%$ level for two-tailed tests. 


\section{Table 11a}

Univariate results for board retirement policy.

\begin{tabular}{llllll}
\hline & bAge limit $=1$ & \multicolumn{2}{c}{ bAge limit $=0$} & Mean \\
& Mean & $\mathrm{N}$ & $\mathrm{Mean}$ & $\mathrm{N}$ & comparison \\
\hline COB age & 57.68 & 285 & 56.52 & 1,195 & $* *$ \\
Survey time & 21.82 & 257 & 21.51 & 1,074 & - \\
\hline
\end{tabular}

The table shows mean comparison tests of $C O B$ age and Survey time for firms with and without mandatory retirement age. ** Significance at the $5 \%$ level for two-tailed tests. 


\section{Table 11b}

Firm performance and board retirement policy.

\begin{tabular}{lcc}
\hline & Dependent variable: ROA & $(1)$ \\
\hline COB age & $-0.093^{* * *}$ & $-0.073^{* *}$ \\
& $(0.035 ;-11.6)$ & $(0.036 ;-9.1)$ \\
bAge limit & 0.304 & 0.326 \\
& $(0.753)$ & $(0.751)$ \\
COB age $\times$ bAge limit & 0.099 & 0.090 \\
Survey time & $(0.088)$ & $(0.088)$ \\
& & $-0.096^{* * *}$ \\
COB tenure & & $(0.027 ;-11.7)$ \\
& 0.040 & 0.042 \\
Other controls & $(0.033)$ & $(0.035)$ \\
Industry fixed effects & Included & Included \\
Observations & Included & Included \\
Adjusted R-squared & & 658 \\
\hline
\end{tabular}

The table investigates whether the presence of a mandatory retirement age (bAge limit) affects the relation between COB age and firm performance. COB age is demeaned. The results are from multivariate OLS regressions. The dependent variable is $R O A$. To preserve space, we do not report the coefficients of the control variables. The first argument in parentheses shows robust standard errors. For significant variables, we add a second argument that shows the sensitivity of the dependent variable (in \%) to an increase in the independent variable by one standard deviation.

* Significance at the $10 \%$ level for two-tailed tests.

** Significance at the $5 \%$ level for two-tailed tests.

*** Significance at the $1 \%$ level for two-tailed tests. 